\title{
Selected Detention Ponds: SH 36 from FM 2218, Fort Bend County to FM 1495, Brazoria County
}

Joel Butler

Follow this and additional works at: https://scholarworks.sfasu.edu/ita

Part of the American Material Culture Commons, Archaeological Anthropology Commons, Environmental Studies Commons, Other American Studies Commons, Other Arts and Humanities Commons, Other History of Art, Architecture, and Archaeology Commons, and the United States History Commons

Tell us how this article helped you.

This Article is brought to you for free and open access by the Center for Regional Heritage Research at SFA ScholarWorks. It has been accepted for inclusion in Index of Texas Archaeology: Open Access Gray Literature from the Lone Star State by an authorized editor of SFA ScholarWorks. For more information, please contact cdsscholarworks@sfasu.edu. 
Selected Detention Ponds: SH 36 from FM 2218, Fort Bend County to FM 1495, Brazoria County

\section{Creative Commons License}

\section{(c) (1) \&}

This work is licensed under a Creative Commons Attribution-NonCommercial 4.0 International License 


\section{Selected Detention Ponds: SH 36 from FM 2218, Fort Bend County to FM 1495, Brazoria County}

Joel Butler

Follow this and additional works at: https://scholarworks.sfasu.edu/ita

Part of the American Material Culture Commons, Archaeological Anthropology Commons, Environmental Studies Commons, Other American Studies Commons, Other Arts and Humanities Commons, Other History of Art, Architecture, and Archaeology Commons, and the United States History Commons

Tell us how this article helped you. 
Selected Detention Ponds: SH 36 from FM 2218, Fort Bend County to FM 1495, Brazoria County

Creative Commons License

(c) (i)

This work is licensed under a Creative Commons Attribution 4.0 License. 


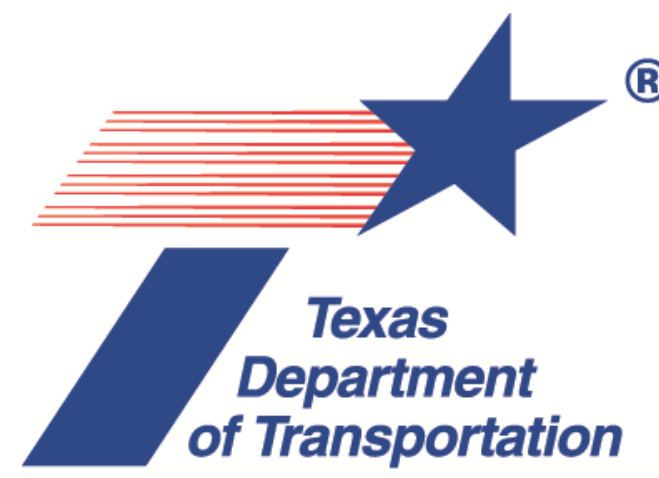

(B)

\section{Report for Archeological Survey \\ Selected Detention Ponds: SH 36 from FM 2218, Fort Bend County to FM 1495, Brazoria County}

CSJs: 0188-04-044; 0187-05-050; 0187-05-048; 0188-02-029; 0188-02-036; 0188-03-019; 011108-100; 0188-04-035; 0188-04-025; 0188-05-027; and 0188-06-046

Joel Butler, Principal Investigator; Antiquities Permit No. 8868

May 2019

The environmental review, consultation, and other actions required by applicable Federal environmental laws for this project are being, or have been, carried-out by TxDOT pursuant to 23 U.S.C. 327 and a Memorandum of Understanding dated December 16, 2014, and executed by FHWA and TxDOT. 
THIS PAGE IS INTENTIONALLY BLANK 


\section{Abstract}

On behalf of CP\&Y and the Texas Department of Transportation (TxDOT), AmaTerra Environmental conducted an intensive archeological survey of two of five proposed detention ponds in Brazoria and Fort Bend Counties, Texas. The detention ponds are part of TxDOT's proposed widening of State Highway (SH) 36 from Farm to Market Road (FM) 2218 in Pleak, Fort Bend County to FM 1495 in Freeport, Brazoria County, Texas (CSJs 0187-05-050, 0188-02-029, 0188-03-019, 0188-04-035, 0188-04-025, 0188-05-027, 0188-06-046, 0111-08-100, 0187-05-048, 0188-04-044, and 0188-02-036). The project was completed in compliance with Section 106 of the National Historic Preservation Act (Section 106) and the Antiquities Code of Texas (ACT) under Permit no. 8868.

Work was conducted April 17, 2019 by a team of two archeologists and consisted of visual inspection and shovel testing of two proposed pond locations (Varner Creek and Pond B). A total of 21 shovel tests were excavated and one new archeological site (41B0282) was recorded. This midtwentieth century site, recorded in the proposed Pond $B$ location, retains little to no data potential within the APE. It is therefore recommended not eligible for listing on the National Register of Historic Places or as a State Antiquities Landmark.

Access was not available at the time of survey for proposed detention Pond A. However, it was visually inspected from the existing right-of-way (ROW) and its current use as a paved construction staging area indicates that archeological resources are unlikely to exist at the location. Therefore, no further work is recommended for this pond site.

Rights of Entry (ROE) were not available at the time of survey for the remaining proposed pond locations (Big Creek 1 and Big Creek 2). AmaTerra recommends intensive archeological survey for these areas when access becomes available and prior to construction. 
THIS PAGE IS INTENTIONALLY BLANK 


\section{TABLE OF CONTENTS}

Abstract.

Project Information 1

Project Description. 1

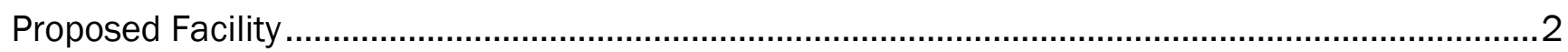

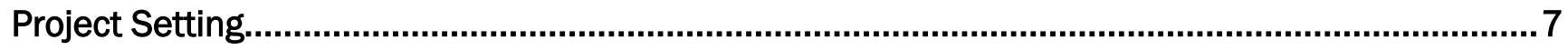

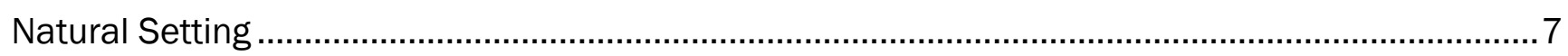

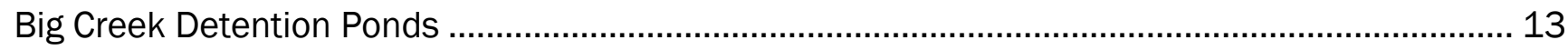

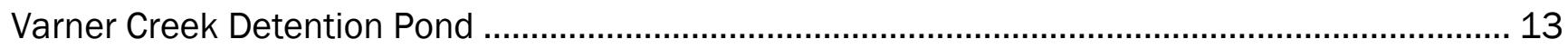

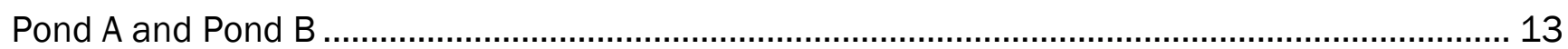

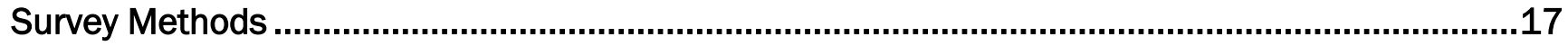

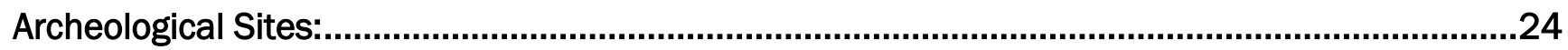

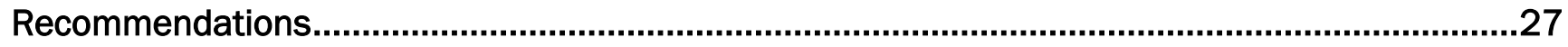

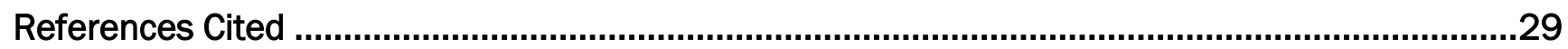

\section{LIST OF FIGURES}

Figure 1. Project location and detention pond locations. ..................................................... 3

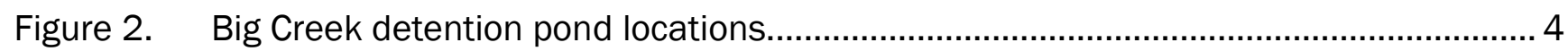

Figure 3. Varner Creek detention pond location.............................................................. 5

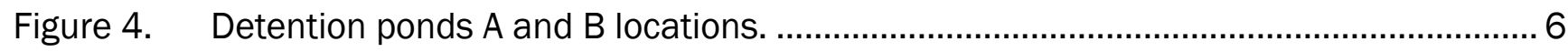

Figure 5. Soils overlapping proposed detention pond locations. ............................................. 8

Figure 6. Houston area PALM overlay of the proposed detention pond locations........................ 9

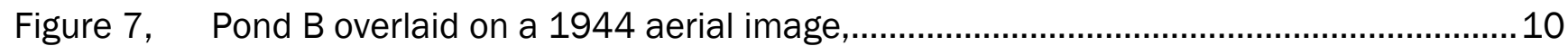

Figure 8. Pond A overlaid on the 1952 West Columbia USGS topographic map........................11

Figure 9. Pond B overlaid on the 1952 West Columbia USGS topographic map........................12

Figure 10. Previous archeological surveys within one kilometer of the Big Creek detention pond

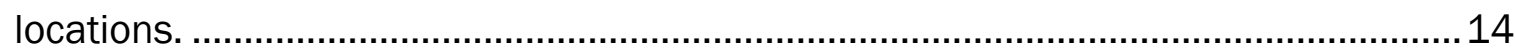

Figure 11. Previous archeological surveys within one kilometer of the Varner Creek detention pond location........................................................................................................15

Figure 12. Previous archeological surveys, sites, and cemeteries within one kilometer of Ponds

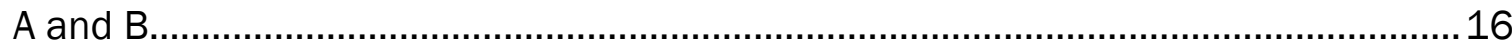

Figure 13. Proposed Varner Creek detention pond, north of Varner Creek, facing southwest. ...20

Figure 14. Proposed Varner Creek detention pond, south of Varner Creek, facing southwest....20

Figure 15. Shovel tests within the proposed Varner Creek pond location..................................21

Figure 16. Proposed Pond A location at the time of survey, facing northwest.............................22

Figure 17. Survey results map within the proposed Pond $B$ location..........................................23

Figure 18. Vacant lot at site 41B0282 from shovel test AG5, facing east..................................25 
Figure 19. Differential vegetation growth above former sidewalk, facing west. .........................25

Figure 20. Concrete sidewalk remnants just below the surface. ............................................26

\section{LIST OF TABLES}

Table 1. Two Previously Recorded Sites within one kilometer of the APE. ................................. 17

Table 2. Subsurface Probe Summary .................................................................................... 18 


\section{Project Information}

- This survey is:

- $\square$ The initial survey for this project

- $\checkmark$ a continuation of previous survey(s) due to:

- $\checkmark$ access issues and/or

$-\checkmark$ design changes

- Date: 5/6/2019

- Date(s) of Survey: 4/17/2019

- Archeological Survey Type:

$\square$ Reconnaissance $\bigotimes$ Intensive

- Report Version:

$\bigotimes$ Draft

$\square$ Final

- Jurisdiction:

$\bigotimes$ Federal

$\bigotimes$ State

- District: Houston

- County or Counties: Brazoria

- USGS Quadrangle(s): West Columbia

- Highway: SH 36

- CSJ: 0187-05-050, 0188-02-029, 0188-03-019, 0188-04-035, 0188-04-025, 0188-05-027, 0188-06-046, 0111-08-100, 0187-05-048, 0188-04-044, and 0188-02-036

- Report Author(s): Amy M. Goldstein

- Texas Antiquities Permit Number: 8868

- Principal Investigator: Joel Butler

- Estimated Percentage of Time that the Principal Investigator Was in the Field: 0 percent

\section{Project Description}

- Project Type: Detention Ponds

- Total Project Acreage: 25.3

- Existing ROW Acreage: 0

- New Right of Way (ROW) Acreage: 25.3

- New Easement Acreage (includes temporary and permanent easements): 0 acres

- Survey Area: 25.3 acres

- Project Description and Impacts: 


\section{Proposed Facility}

TxDOT - Houston District proposes to widen SH 36 from FM 2218 in Pleak, Fort Bend County to FM 1495 in Freeport, Brazoria County, Texas (Figures 1-4). The total project length is 51 miles. The proposed roadway improvements would upgrade $\mathrm{SH} 36$ with designated hurricane evacuation routes, to increase safety, access and mobility for the transportation of people and commercial goods in coastal areas in emergency situations. The proposed roadway for rural areas would consist generally of an open ditch section with four 12-foot lanes, two 10-foot outside shoulders, two 8-foot inside shoulders and a 68-81-foot depressed grassy center median. For urban areas, the roadway would generally consist of four 12-foot lanes, a 14-16-foot flush median (center left-turn lane) with either ditches or a curb and gutter design.

- An archeological survey of the SH 36 expansion from FM 2218 to FM 1495 in Freeport to support a NEPA document was completed in 2004 and found that no further archeological work was necessary except at three locations (two at Big Creek and one at Varner Creek) where detention ponds would have deep impacts in areas where archeological potential exists. Two additional ponds have since been added to the design; these two locations (Ponds A and B) are included in this survey.

- Area of Potential Effects (APE): For the present survey, the APE is defined as the footprint of the proposed detention ponds to their maximum depth of impact. Therefore, the APE for this survey is considered to total 25.3 acres spread across five locations, to a maximum depth of 15 feet.

- No Survey Area: 19.7 acres

- Access Denied Area: Access was denied at the Pond A, Big Creek 1 and Big Creek 2 proposed pond locations, totaling 19.7 acres.

- Survey Area: Two out of five proposed detention pond locations were physically surveyed. These were the Varner Creek and Pond B locations, which total 5.6 acres in area. Access was denied at the Pond A location, but it was visually inspected from the existing ROW. The Big Creek detention pond locations were not surveyed but have potential to contain archeological material and should therefore be subject to intensive survey prior to construction.

Parcel Number(s): 189794, 189795 (Pond B) \& 163533, 163616 (Varner Creek)

Project Area Ownership: Private 


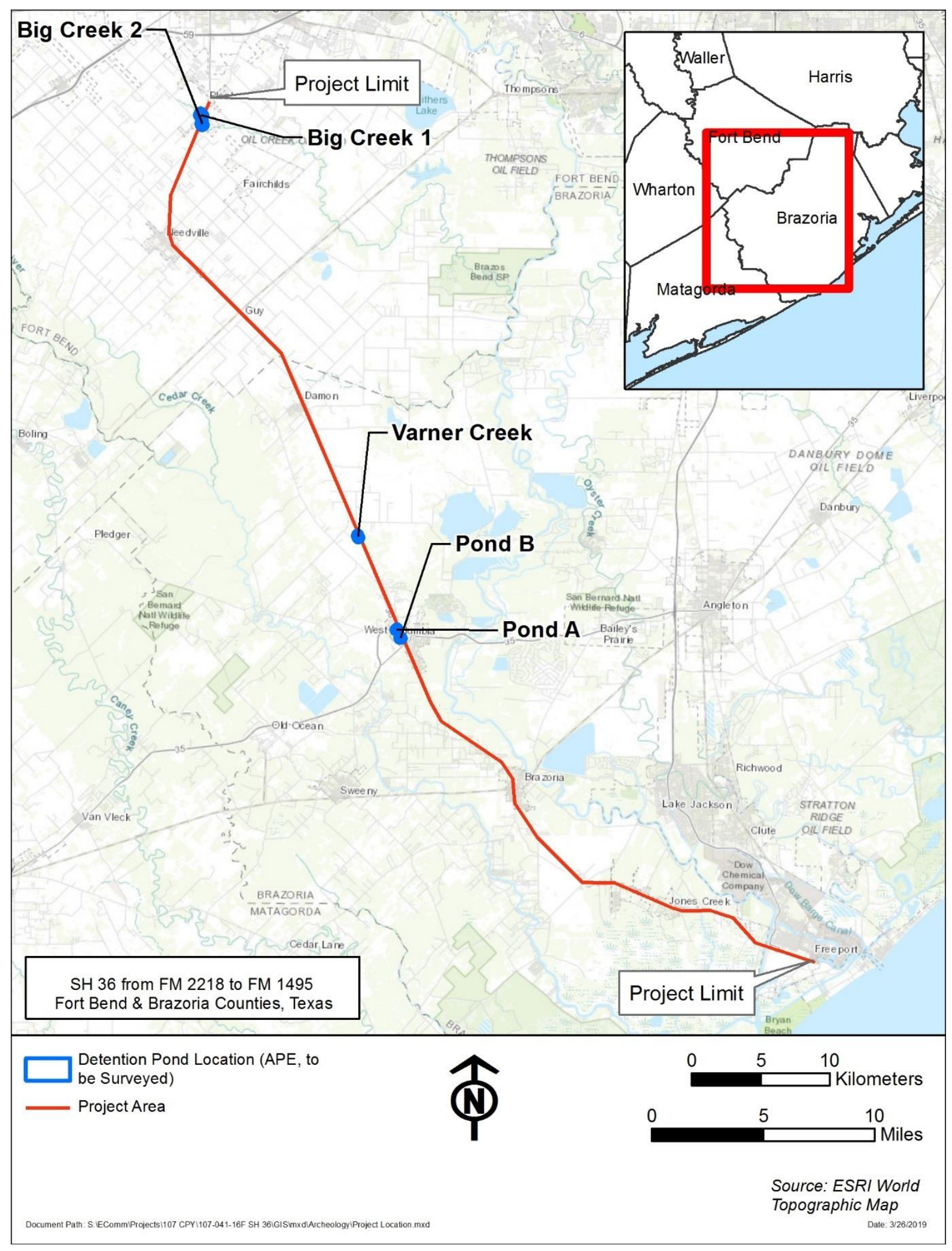

Figure 1. Project location and detention pond locations. 


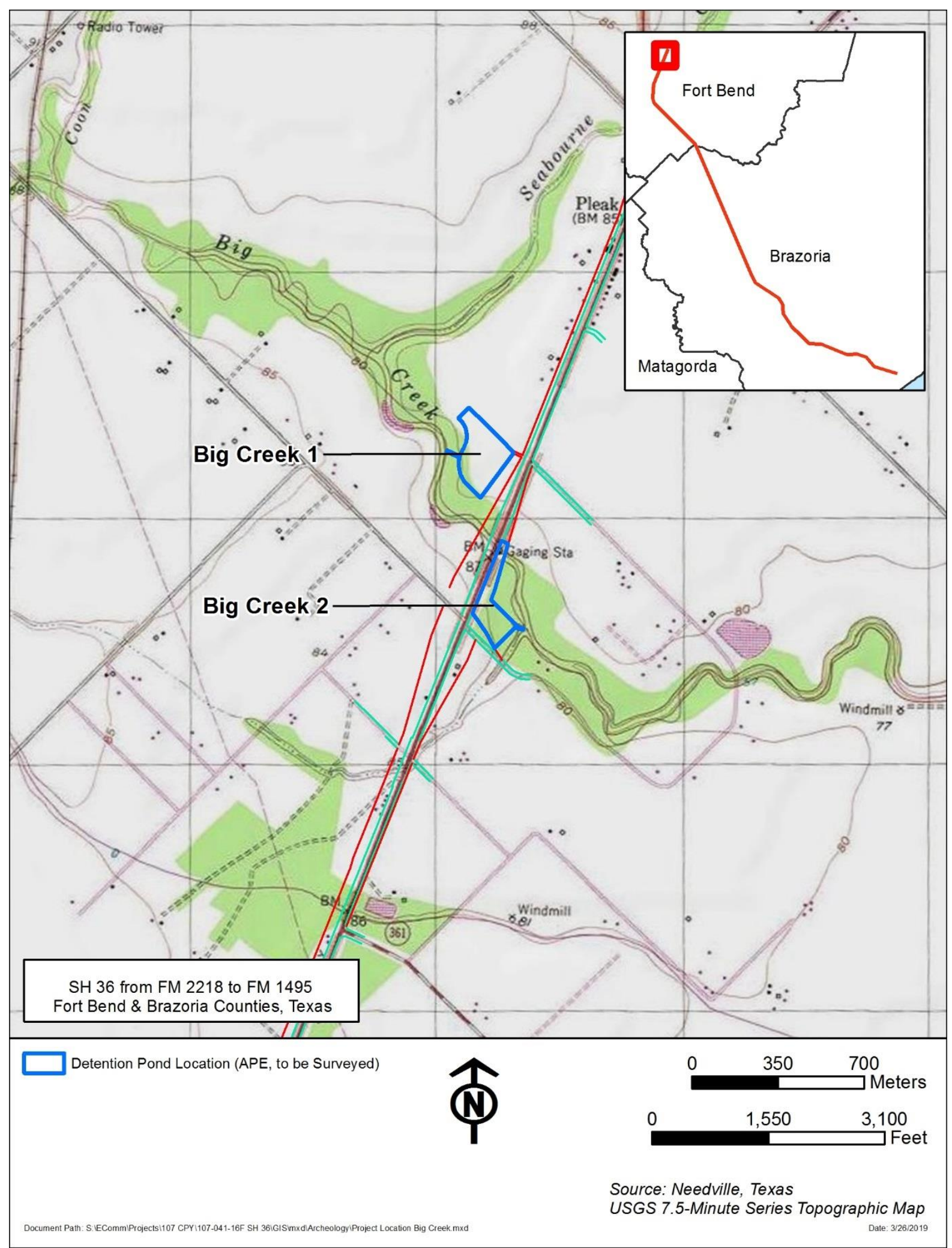

Figure 2. Big Creek detention pond locations. 


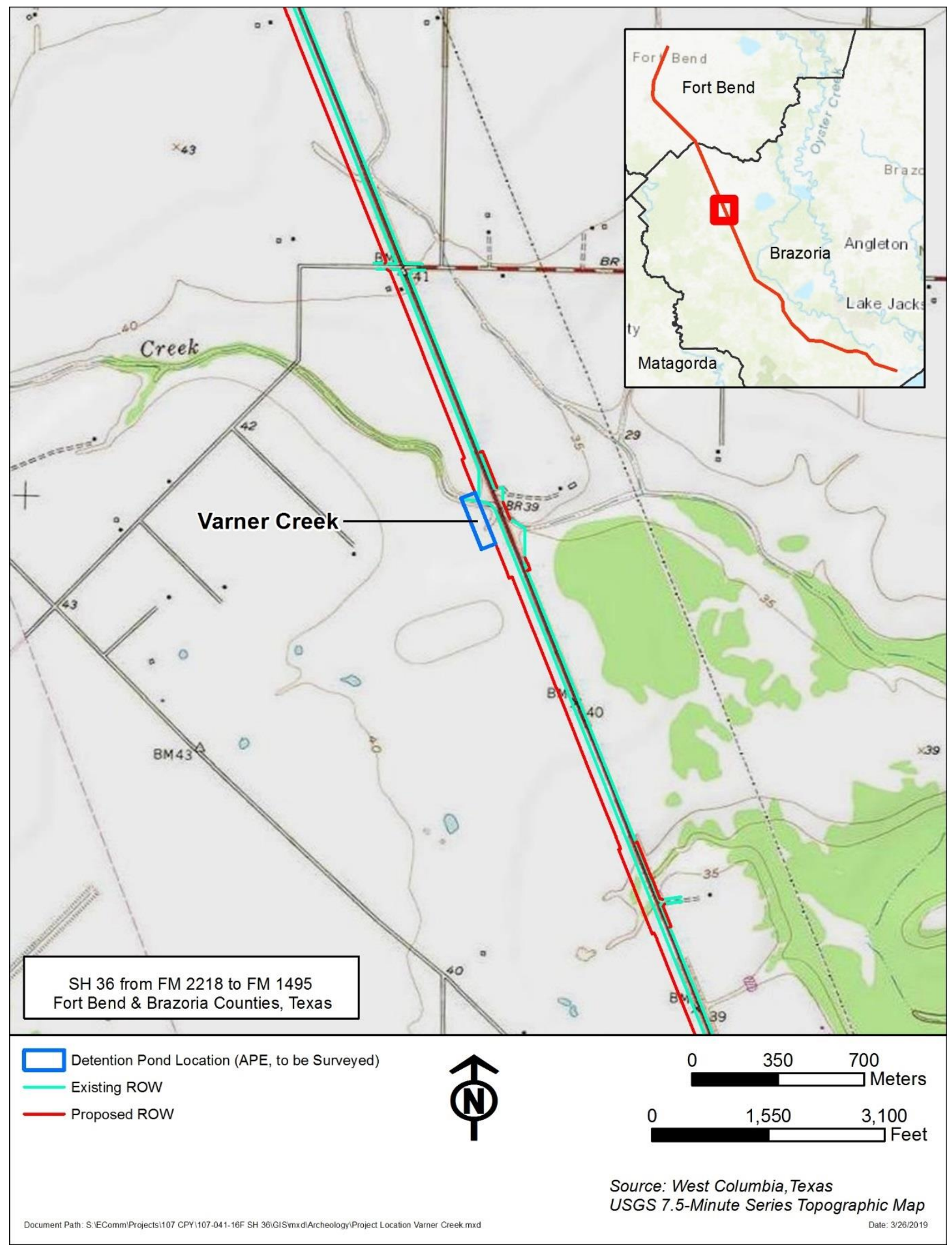

Figure 3. Varner Creek detention pond location. 


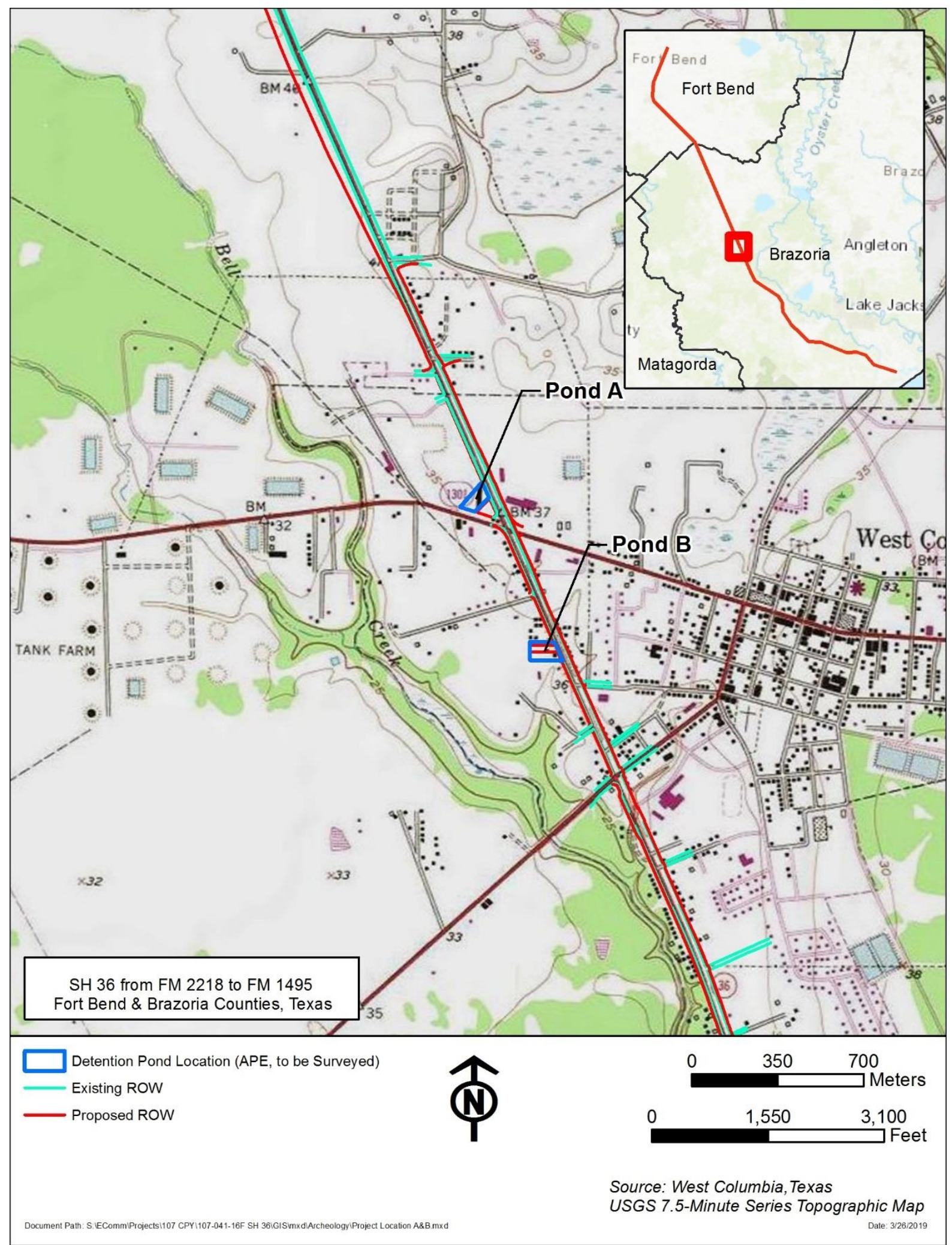

Figure 4. Detention Ponds A and B locations. 


\section{Project Setting}

\section{Natural Setting}

Topography: Topography throughout the APE is relatively flat. Elevation ranged from 30-40 feet above mean sea level (amsl) across the two surveyed pond locations. The three pond locations that were not surveyed are also generally flat.

Geology: According to the Geologic Atlas of Texas, Houston Sheet (1976), the APE bisects Quaternary-age deltaic clay, silt, and sand of the Beaumont Formation (Qb).

Soils: Soils are often described as dark, clayey soils associated with Vertisols, or surficial layers of shrinking and swelling clays (Omernik and Griffith 2009). Within the APE, surface soils include a variety of deep clays and loamy clays (USDA-NRCS 2019) (Figure 5). The average depth to a restrictive feature is greater than 80 inches. Although these soils are deep, they are mostly ancient and have very low potential to contain buried archeological sites.

Potential Archeological Liability Map: The Houston District Potential Archeological Liability Model (PALM; Abbott 2001) shows the survey areas fall into Units 1 (surface survey recommended; trenching recommended for deep impacts), 2 (surface survey recommended), and 4 (no survey recommended; Figure 6).

Vegetation: Vegetation within the Gulf Coast Prairies and Marshes is characterized by grasslands with a few clusters of oak mottes or maritime woodlands. Today, common grasses included little bluestem (Schizachyrium scoparium var. frequens), yellow Indiangrass (Sorghastrum nutans), brownseed paspalum (Paspalum plicatulum), gulf muhly (Muhlenbergia capillaries), and switchgrass (Panicum virgatum) (Gould 1978). Common trees found within the region include Live oak (Quercus virginiana), southern red cedar (Juniperus virginiana var. silicicola), the Durand white oak (Quercus sinuata), Texas persimmon (Diospyros texana), sugarberry (Celtis laevigata), pecan (Carya illinoinensis), and gum bumelia (Sideroxylon lanuginsoum). By the early 1900s, most of the natural vegetation within the ecoregion had been altered for suitable crop and rangeland. The principal crops grown within this region are rice, grain sorghum, sugar, cotton, pecans, and soybeans (Omernik and Griffith 2009).

- Estimated Ground Surface Visibility: 0-10\%

- Human Environment: N/A

- Historic Land Use: The project area consisted of farms and ranches for much of its history, with oil or natural gas wells becoming a feature of the landscape in the 1920s. Aerial imagery and historic maps show no structures or obvious landscape modifications for the Big Creek or Varner Creek pond sites. However, Pond B has several structures visible in its footprint in 1944 aerial imagery (Figure 7) and both Ponds A and B have buildings on 1952 topographic maps 
(Figure 8-9). The structures depicted at Pond B appear to be domestic dwellings or commercial buildings, and the structure at Pond A appears to be a poultry barn or some other outbuilding.

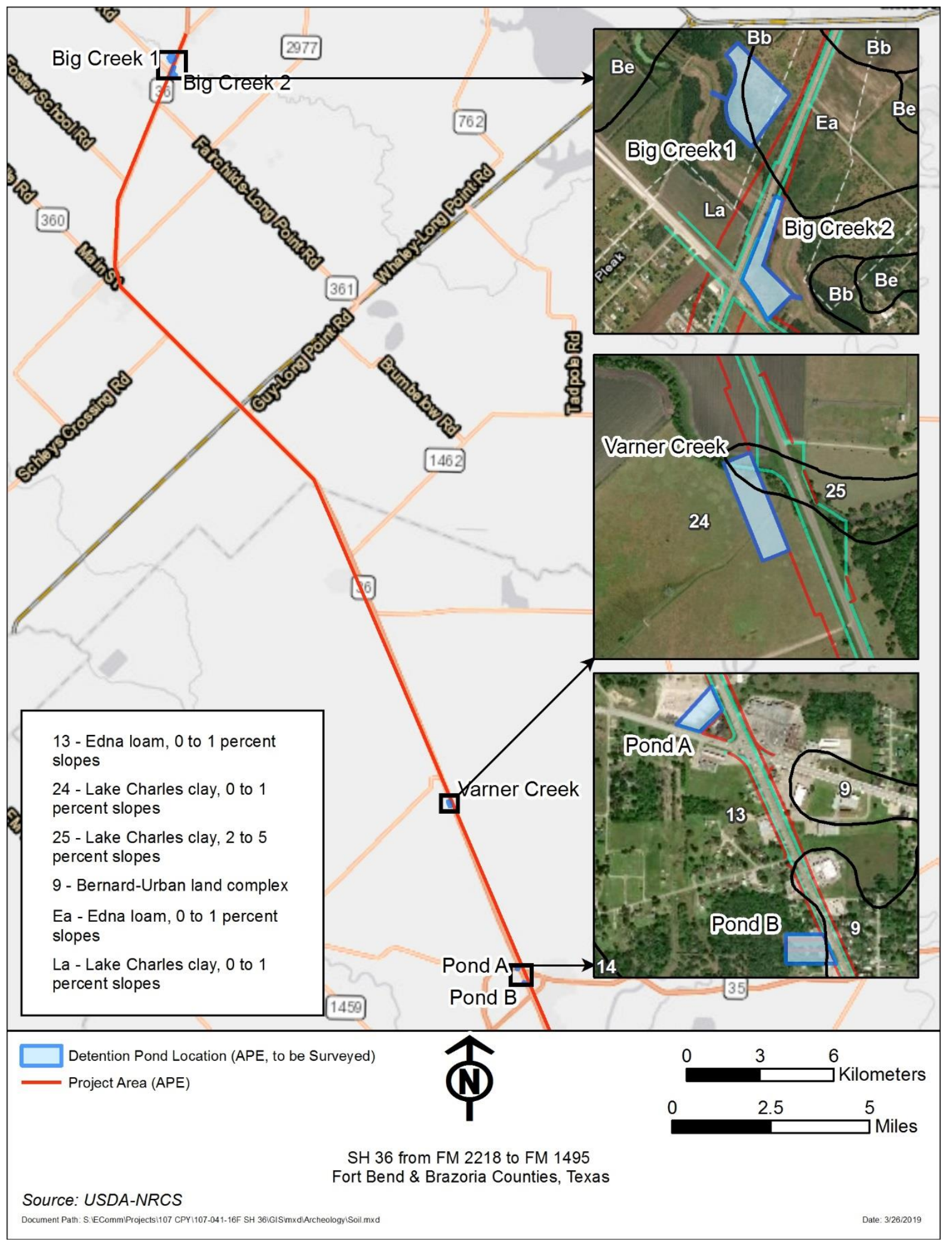

Figure 5. Soils overlapping proposed detention pond locations. 


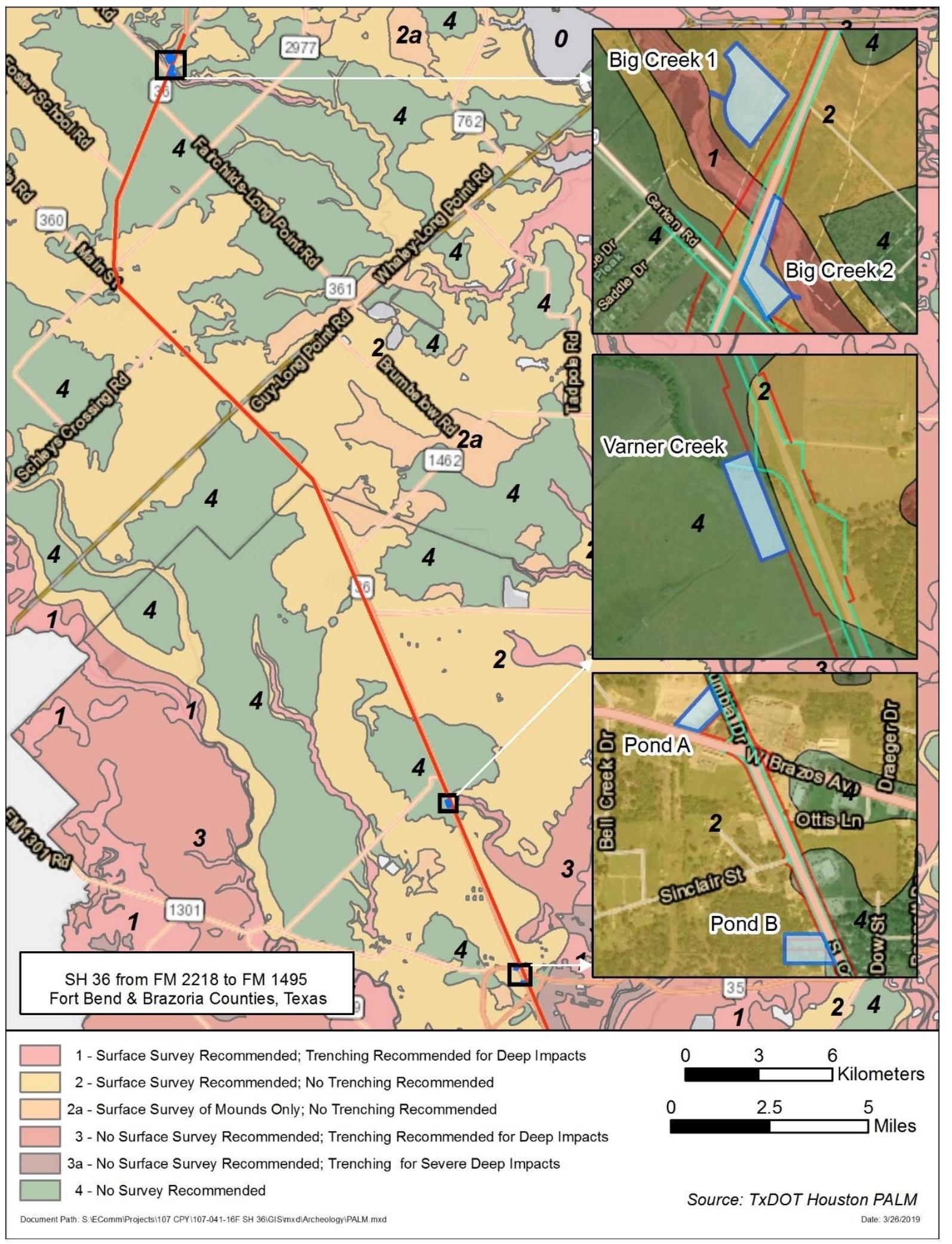

Figure 6. Houston area PALM overlay of the proposed detention pond locations. 


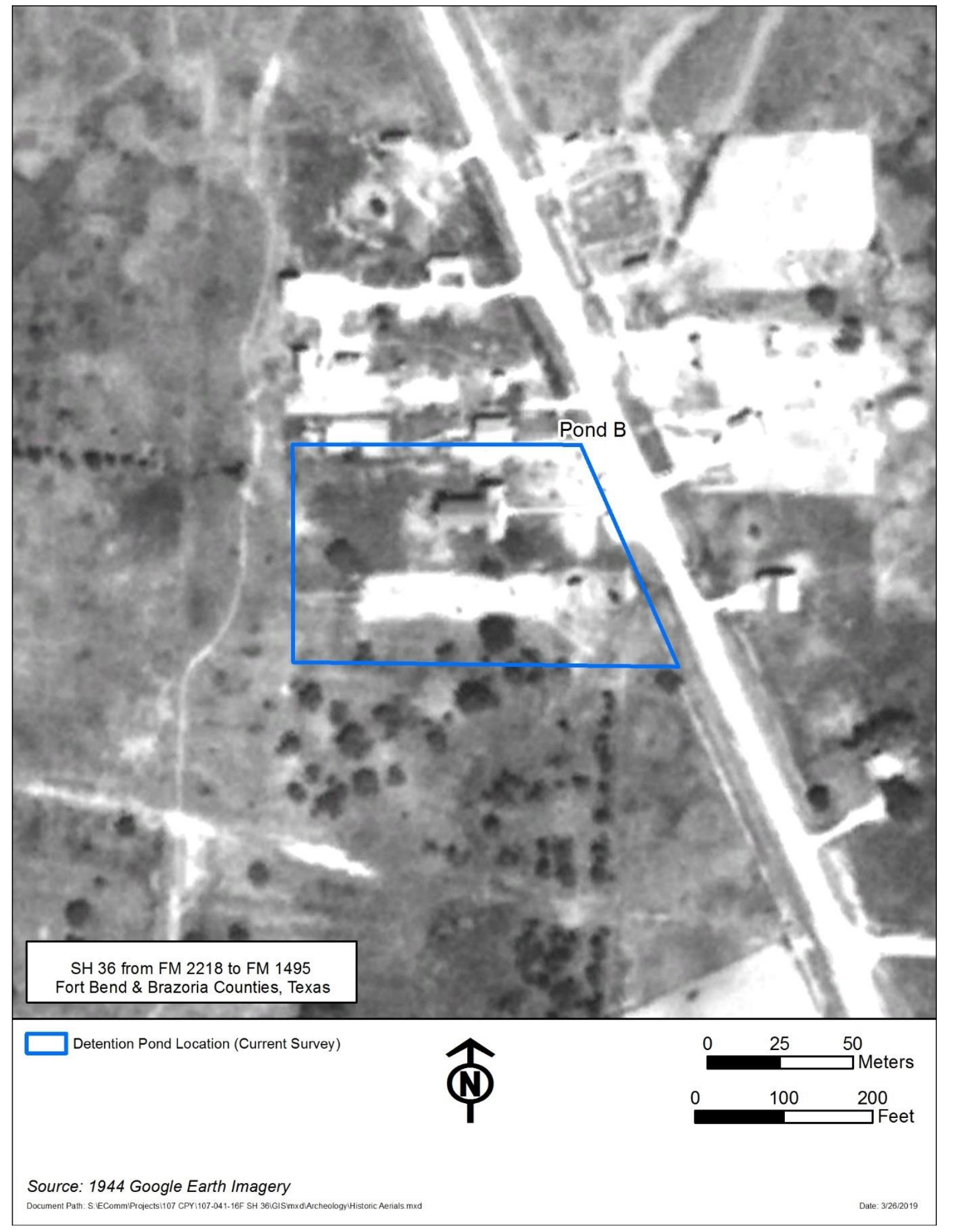

Figure 7. Pond B overlaid on a 1944 aerial image. 


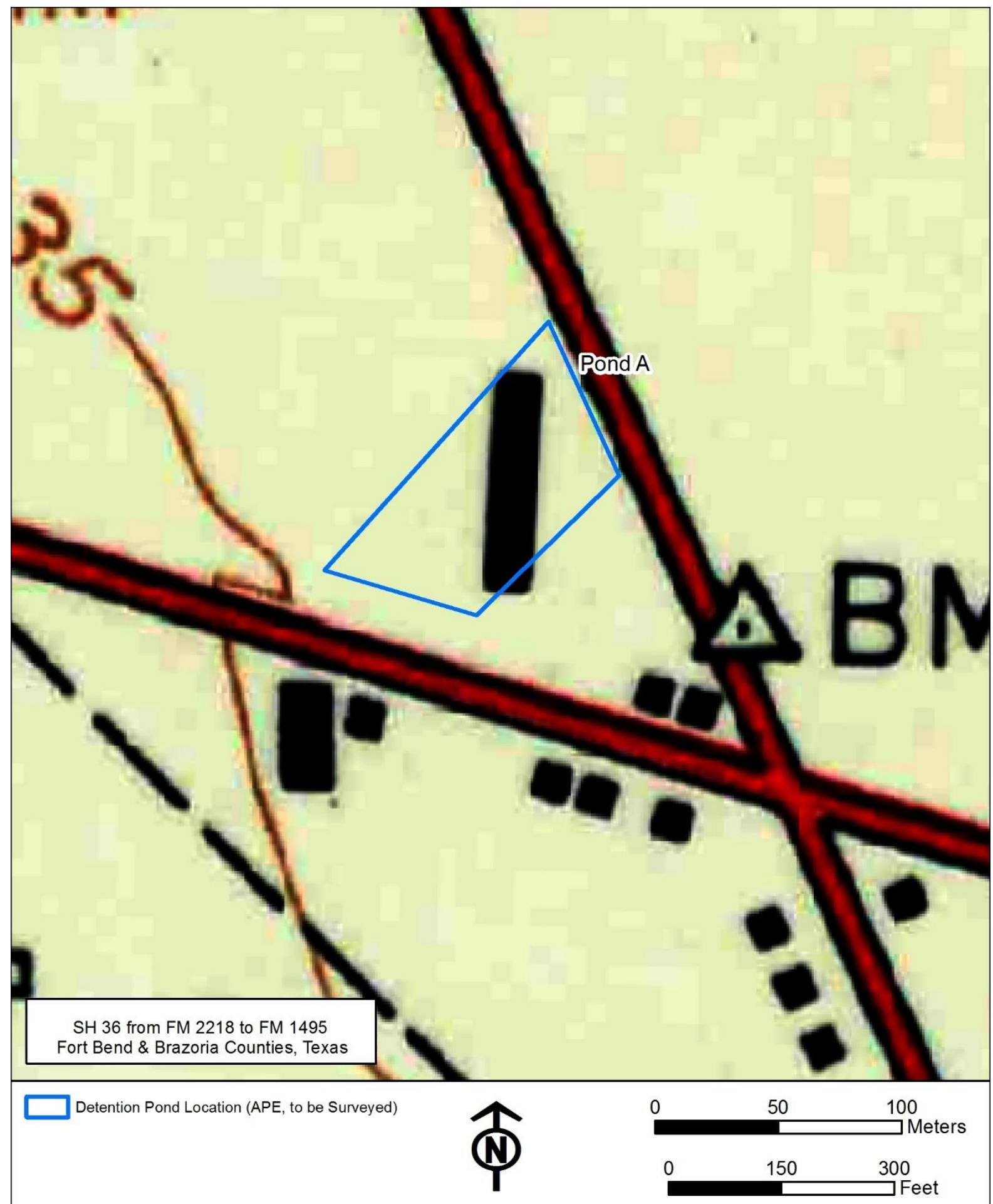

Source: 1952 West Columbia, Texas

USGS 7.5-minute Topographic Map

Document Path: S. ECommiProjects1107 CPYI107-041-16F SH 36iGISimxdIArcheologyiHistoric Topo.mxd

Figure 8. Pond A overlaid on the 1952 West Columbia USGS topographic map. 


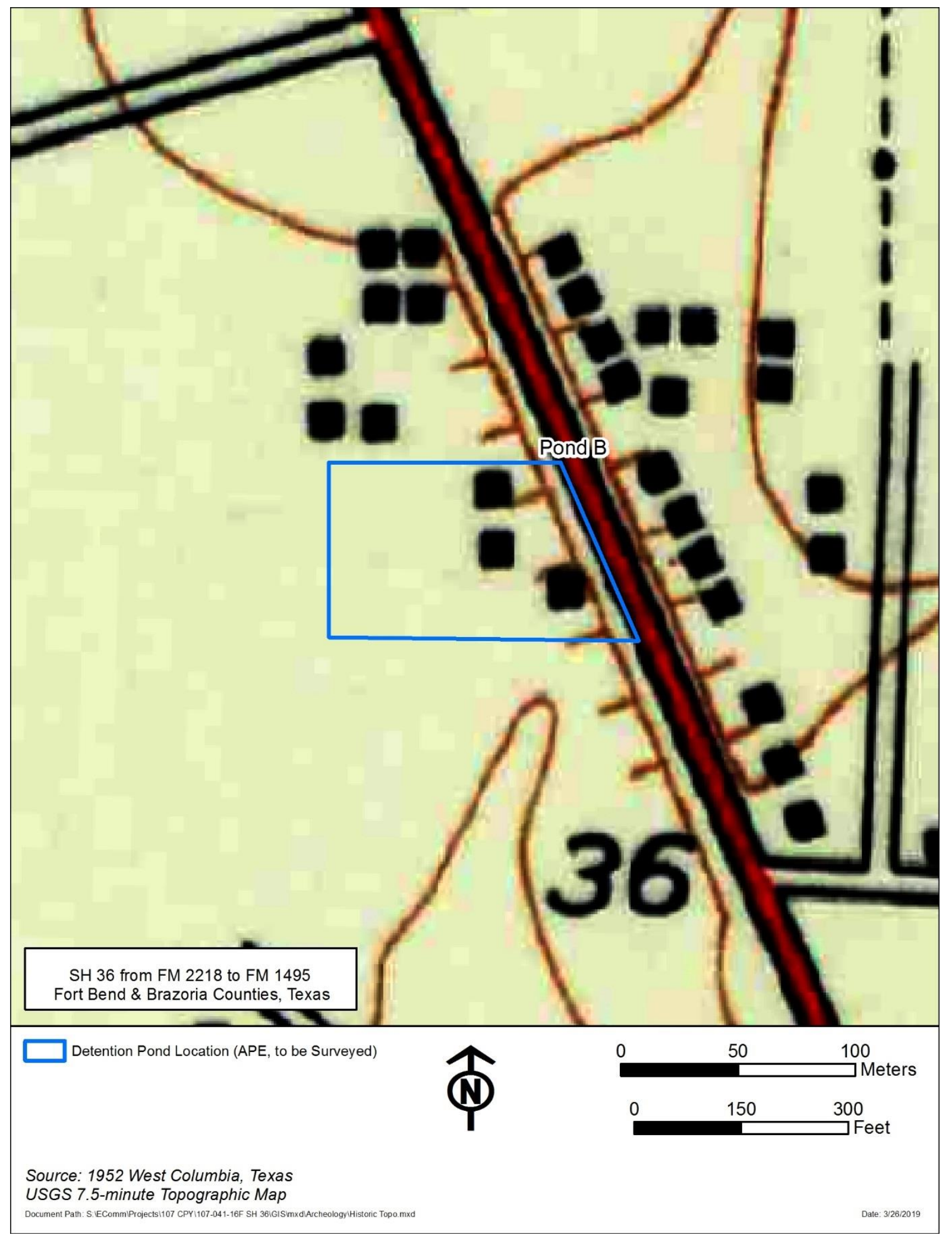

Figure 9. Pond B overlaid on the 1952 West Columbia USGS topographic map. 
- Current Land Use: Today the Big Creek and Varner Creek pond locations are used as rangeland. Based on Google Earth imagery, the Pond A location was almost entirely paved over sometime between 2005 and 2006. Since then the area has been used on and off as a staging area for construction, as it was at the time of survey. The Pond B location currently consists of a house (in use) and its associated yard and woods in the southern half and a vacant grassy lot in the north half.

- Previous Investigations and Known Archeological Sites: A background literature review found three previous archeological surveys within one kilometer of the APE, two of which overlap or intersect with the APE. No previously recorded archeological sites overlap the APE, though two are within one kilometer (THC 2019). These are described in detail below.

\section{Big Creek Detention Ponds}

Two previous archeological surveys have been carried out within one kilometer of the Big Creek Detention Pond Locations (Figure 10): a 1999 US Army Corps of Engineers (USACE) survey along Big Creek and the 2002 SH 36 survey by Moore Archaeological Consulting (MAC). No sites or other previously documented cultural items of interest are located within one kilometer of these pond locations.

\section{Varner Creek Detention Pond}

One previous archeological survey (the 2002 SH 36 survey by MAC) is located adjacent to the proposed pond location (Figure 11). There are no previously documented archeological sites or other items of cultural interest are located within one kilometer of the Varner Creek pond site.

\section{Pond $A$ and Pond $B$}

Ponds $\mathrm{A}$ and $\mathrm{B}$ are located in the City of West Columbia and are within one kilometer of two previous surveys (the 2002 MAC SH 36 survey and a 1995 Federal Highways Administration [FHWA] survey along SH 35 west of the project area; Figure 12). Two archeological sites are located within one kilometer of the ponds. Site 41B0186, located 900 meters northwest of Pond A is the George B. McKinstry house site and homestead where the Father of Texas, Stephen F. Austin, died on December 27, 1836. Records on the Texas Archeological Sites Atlas indicate that the house site consists of a scatter Revolution-era artifacts and brick foundation remnants. Site 41B0225, located 900 meters east of Pond B, is the site of the first Capitol of the Republic of Texas in 1836. This site was mitigated by Prewitt and Associates in 2007 in advance of the construction of a drugstore and historic park. Although the Atlas does not list eligibility recommendations for these sites, they are likely eligible for the NRHP and as SALs.

Three cemeteries are located within one kilometer of the proposed pond locations, none of which will be impacted by the project. 


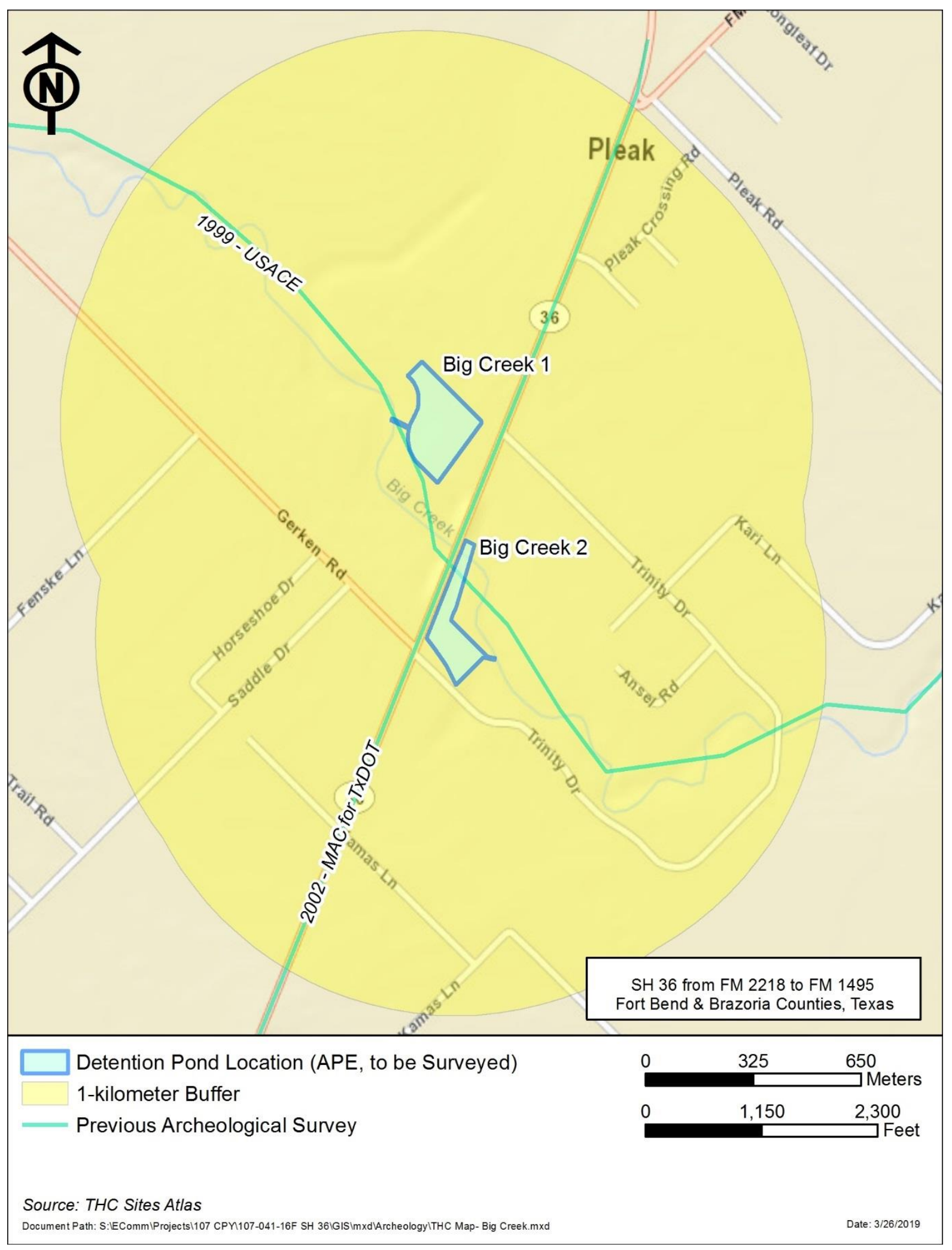

Figure 10. Previous archeological surveys within one kilometer of the Big Creek detention pond locations. 


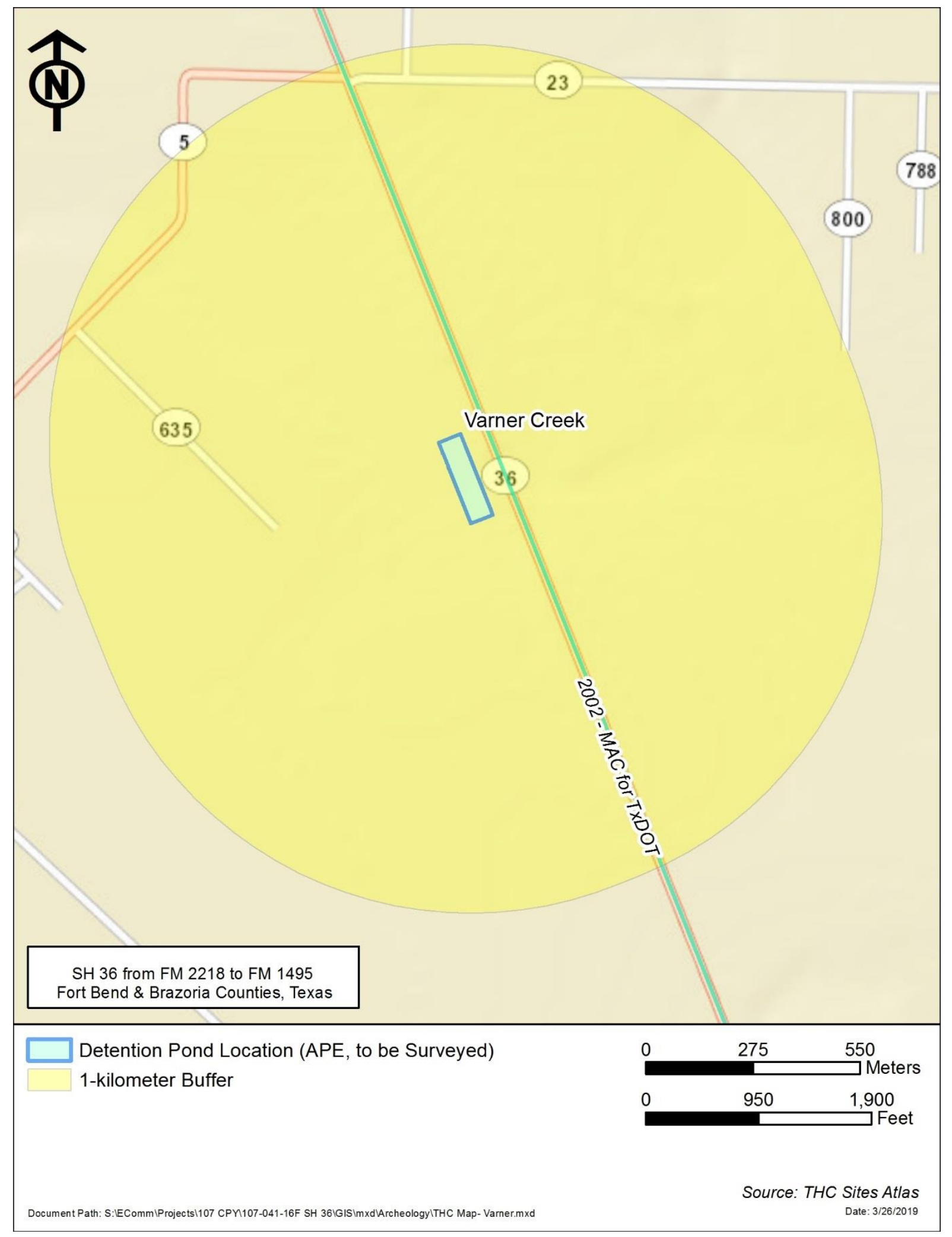

Figure 11. Previous archeological surveys within one kilometer of the Varner Creek detention pond location. 
This figure has been redacted due to site sensitive material.

Figure 12. Previous archeological surveys, sites, and cemeteries within one kilometer of Ponds $A$ and $B$. 
There are two previously recorded sites within a kilometer of the APE. These sites are summarized in Table 1 below.

Table 1. Two Previously Recorded Sites within one kilometer of the APE.

\begin{tabular}{|l|l|l|l|l|}
\hline Site No. & \multicolumn{1}{|c|}{ Site type } & $\begin{array}{l}\text { Record } \\
\text { date }\end{array}$ & $\begin{array}{c}\text { Distance } \\
\text { from APE }\end{array}$ & Eligibility Status \\
\hline \multirow{2}{*}{$41 \mathrm{B0186}$} & Historic homestead & 1994 & $900 \mathrm{~m}$ & $\begin{array}{l}\text { No } \\
\text { Recommendation }\end{array}$ \\
\hline \multirow{2}{*}{$41 \mathrm{~B} 0225$} & $\begin{array}{l}\text { Historic homestead/site of } \\
\text { the first Capitol of Texas }\end{array}$ & 2008 & $900 \mathrm{~m}$ & $\begin{array}{l}\text { No } \\
\text { Recommendation }\end{array}$ \\
\hline
\end{tabular}

- Evaluation of Project Setting: The APE at the Varner Creek pond location consists of an open pasture crossed by Varner Creek and another small drainage. This portion of the APE has had little to no ground disturbance. The Pond A location (which could not be fully surveyed) has been largely modified in the last decade and is now mostly paved. Disturbances in this location have probably been deep enough in the area's upland setting that buried archeological deposits are unlikely. The Pond B location is covered by a house, yard, and dense woods in the south half and a vacant grassy lot in the north half. The northern half has probably been significantly disturbed from razing and clearing the structure that used to be in this location. Disturbance in the south half is probably limited to the surface or just below the surface except where the house is currently located.

\section{Survey Methods}

\section{- Surveyors: Amy Goldstein and Garrett Wheaton}

Description of Methods: Survey efforts involved visual inspection supplemented with excavation of 21 shovel tests at the Varner Creek and Pond B locations (Tables 2 and Attachment A). Subsurface testing followed the minimum standards for surveys in Texas outlined by the Council of Texas Archeologists (CTA) and adopted by the THC. Based on these standards, the Varner Creek pond location (3.4 acres) required a minimum of seven shovel tests and the Pond $B$ location ( 2.2 acres) required a minimum of seven shovel tests. All shovel tests were excavated to a depth of 80 centimeters ( 2.6 feet) below the surface (cmbs) or until pre-cultural soils (subsoil) or restrictive features were reached. Soil from all shovel tests was be screened through $1 / 4$-inch hardware cloth.

Site recording methodology complied with THC/CTA survey standards and policy, including requirements for assessing historic archeological sites and identifying historic cemeteries. Any archeological sites identified within the APE during the survey were investigated by means of no fewer than six subsurface shovel tests in order to define site boundaries relative to the APE. Specific site information was recorded on standardized forms and presented to the Texas Archeological Research 
Laboratory (TARL) for inclusion in their archives. Artifacts found either on the surface or in shovel tests was field catalogued then returned to its original location of discovery. No artifacts were collected during the survey.

- During the course of the survey, investigators took photographs of the landscape, sites, features, and various disturbances encountered. Additionally, site notes and maps were made in the field, and artifacts were documented photographically.

- Subsurface Probes (Table 2)

Table 2. Subsurface Probe Summary.

\begin{tabular}{|l|c|c|c|c|}
\hline Method & $\begin{array}{l}\text { Quantity in } \\
\text { Existing ROW }\end{array}$ & $\begin{array}{l}\text { Quantity in } \\
\text { Proposed } \\
\text { New ROW }\end{array}$ & $\begin{array}{l}\text { Quantity in } \\
\text { Proposed New } \\
\text { Easements }\end{array}$ & $\begin{array}{l}\text { Total Number } \\
\text { per Acre }\end{array}$ \\
\hline $\begin{array}{l}\text { Shovel } \\
\text { Test Pits }\end{array}$ & 0 & 21 & 0 & 3.75 \\
\hline $\begin{array}{l}\text { Power Auger } \\
\text { Probes }\end{array}$ & NA & NA & NA & NA \\
\hline $\begin{array}{l}\text { Mechanical } \\
\text { Trenches/Scrapes }\end{array}$ & NA & NA & NA & NA \\
\hline
\end{tabular}

- Other Methods: None

- Collection and Curation: $\quad \square$ NO $\quad \square$ YES If yes, specify facility

- Comments on Methods: The methods used during the survey exceed the CTA standards, which call for three shovel tests per acre for areas 0-2 acres and two shovel tests per acre for areas three to ten acres. Nine shovel tests were excavated within the 3.4-acre Varner Creek pond area, which exceeds the minimum of seven. Twelve shovel tests were excavated within the 2.2acre Pond $\mathrm{B}$ area, which exceeds the minimum of seven. Additionally, 12 shovel tests were excavated in and around site 41B0282, which exceeds the minimum of six.

\section{Survey Results:}

Survey Area Description: AmaTerra archeologists carried out an intensive survey on April 17, 2019. Field conditions were ideal, and no difficulties affected the survey. Current land use within the APE included rural pasture, paved construction staging area, and a vacant city lot. Significant previous disturbance was only observed at the proposed Pond A location, where paving and use of the area for construction staging. During field investigations one new archeological site, 41B0282, was recorded within the proposed Pond B location. A total of 21 shovel tests were excavated, which are presented in Appendix B. No artifacts were collected during this survey.

To assist with organization, survey area descriptions are organized by pond location. 


\subsection{Varner Creek}

The proposed Varner Creek pond is located west of the current SH 36 ROW, 0.6 miles southeast of the intersection of W Rhodes School Road and SH 36. This detention pond will encompass an area of 3.4 acres. Varner Creek crosses the northeast corner of the pond while a small unnamed drainage crosses the center of the proposed pond. The portion of the pond that is north of Varner Creek is within a plowed agricultural field and a grassy area along the creek bank (Figure 13). South of Varner Creek, the proposed pond area is an open pasture with short grass (Figure 14). Topography is flat except immediately around Varner Creek where elevation decreases.

A total of nine shovel tests were excavated within the proposed pond area; none contained cultural material (Figure 15). A typical soil profile consisted of very dark gray (10YR 3/1) loamy clay to a depth of $20 \mathrm{~cm}$ over black (10YR 2/1) clay to $30+$ cmbs. Because no cultural resources were found within the Varner Creek proposed detention pond, AmaTerra recommends that construction can proceed without further work.

\subsection{Pond $\mathrm{A}$}

The proposed Pond A measures 1.6 acres and is located approximately 320 feet northwest of the intersection of SH 36 and SH 35 in the City of West Columbia. The Pond A portion of the APE was not subject to pedestrian survey or shovel testing because ROE was not available at the time of survey. However, visual inspection of the area from the existing ROW indicates it has been developed and at the time of survey was being used as a construction staging area (Figure 16). Google Earth aerial imagery shows that between 2005 and 2006 most of the proposed Pond A and adjacent areas were paved; since that time it has been used for construction staging or other industrial uses. USDA-NRCS Soil Web shows that the underlying soil throughout Pond $A$ is Edna loam. This soil is of Pleistocene age and has an A horizon that extends to $23 \mathrm{cmbs}$. Given that the upper $30 \mathrm{~cm}$ or more of soil have been disturbed by clearing and paving, it is unlikely that intact archeological deposits of either prehistoric or historic age could be present within the APE and proposed Pond A. AmaTerra recommends that no further work at this location is necessary.

\subsection{Pond $\mathrm{B}$}

The proposed Pond B is located within the City of West Columbia, off the southbound side of SH 36 (South Columbia Drive), 550 feet northwest of the intersection of West Jackson Street and SH 36. The APE for Pond B measures 2.2 acres. The north half of this proposed pond location is currently a vacant urban lot that was covered in tall grass at the time of survey. The northernmost area of this pond slightly overlaps a cellular tower and supporting infrastructure; surveyors did not have access to this parcel (Figure 17). The southeast corner of proposed Pond B contains a wooden frame house that is currently occupied. West of the house is an opened backyard that gives way to dense woods. Ground surface visibility was generally poor (0-10 percent) due to tall grass and leaf litter. Like other portions of the APE, Pond $B$ is very flat with elevation ranging from 33-35 feet amsl. 


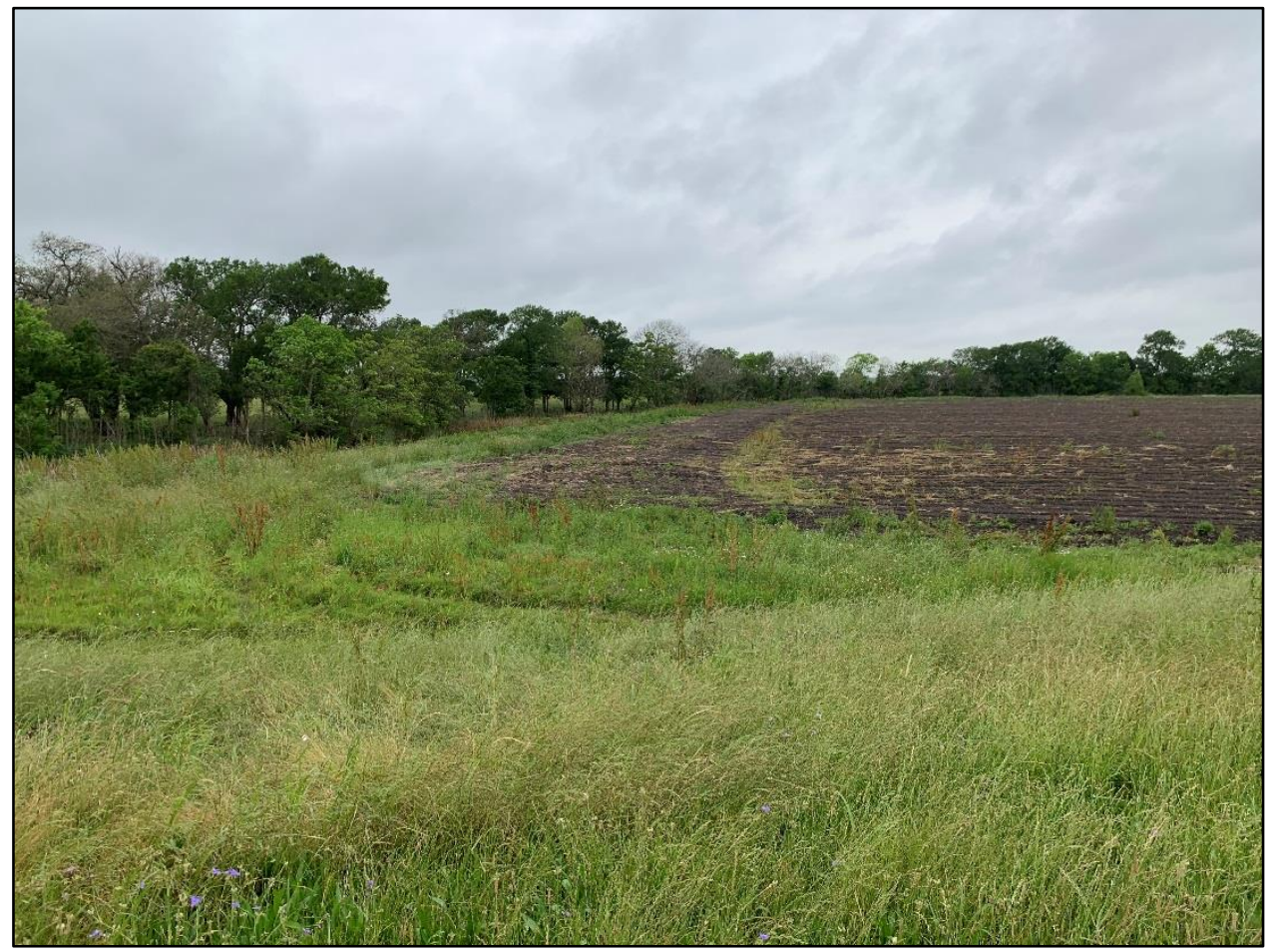

Figure 13. Proposed Varner Creek detention pond, north of Varner Creek, facing southwest.

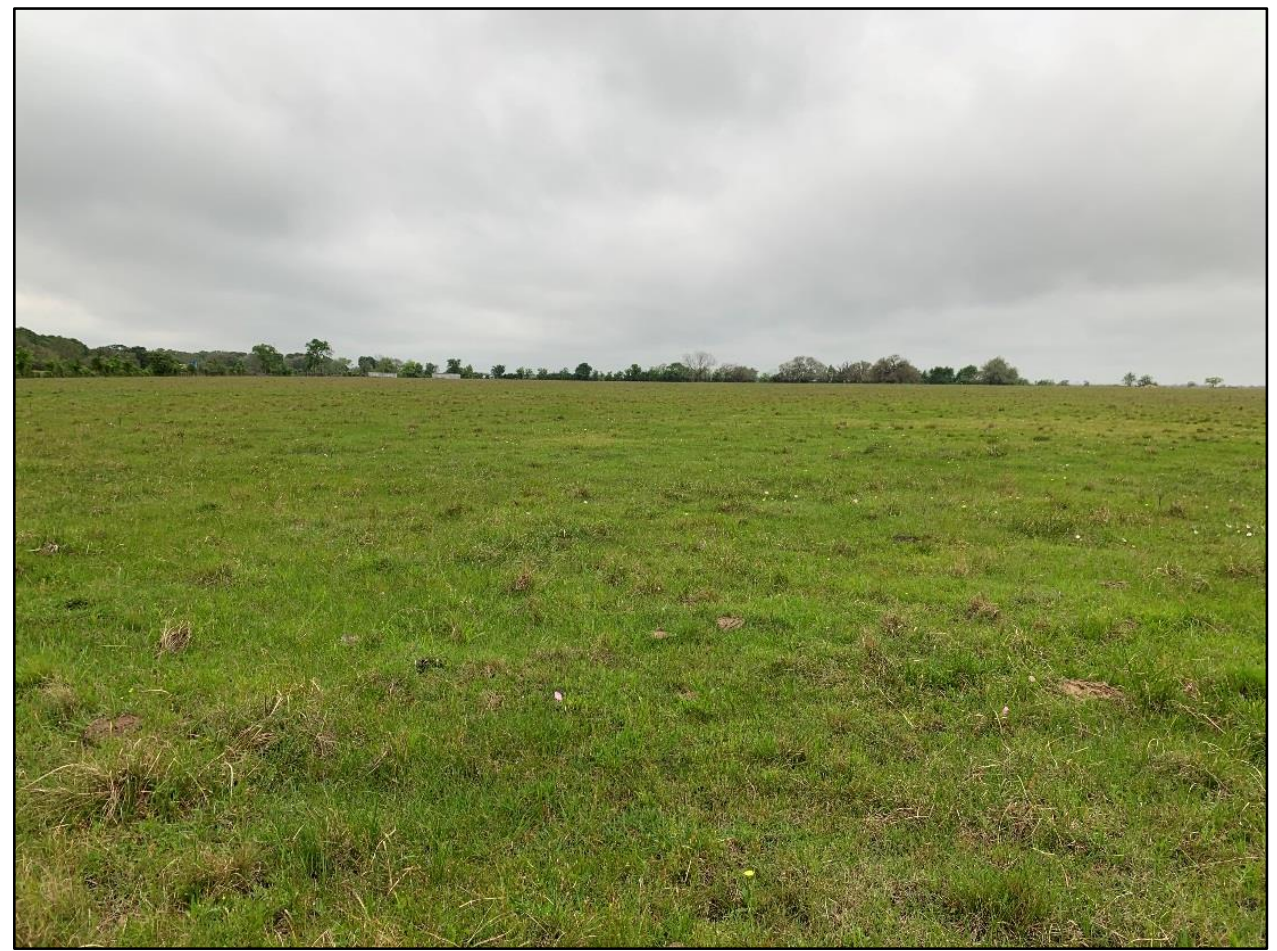

Figure 14. Proposed Varner Creek detention pond, south of Varner Creek, facing southwest. 


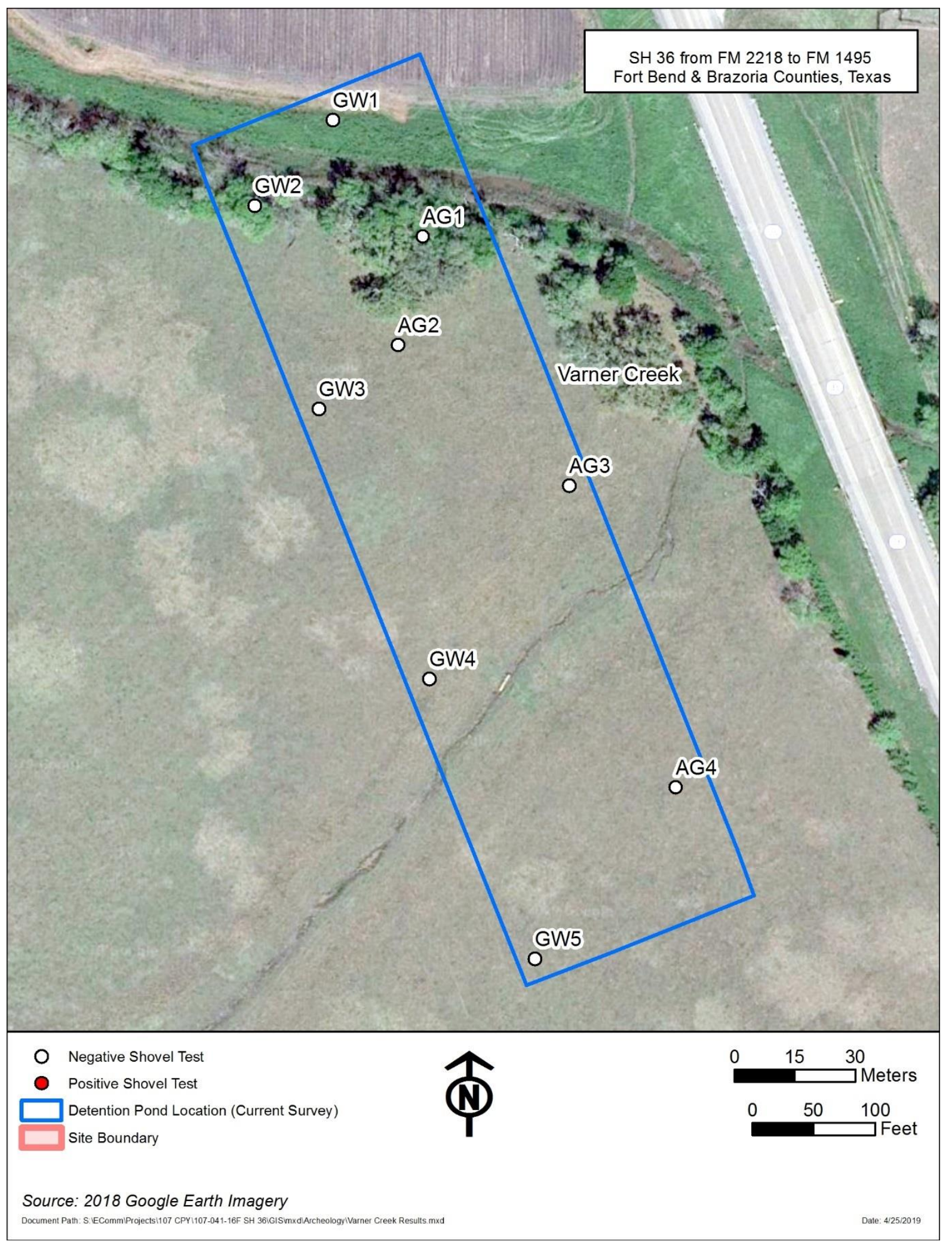

Figure 15. Shovel tests within the proposed Varner Creek pond location. 


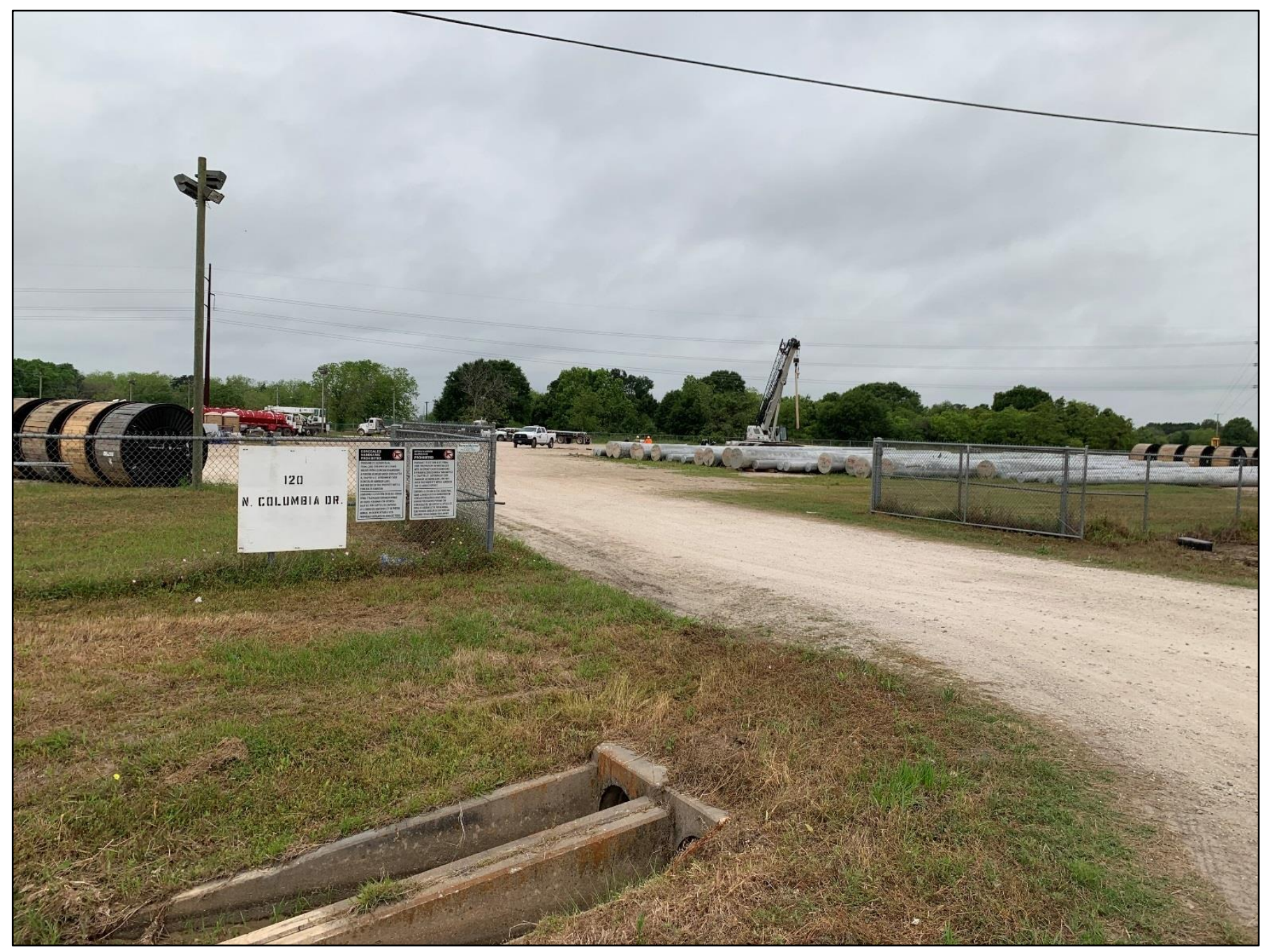

Figure 16. Proposed Pond A location at the time of survey, facing northwest. 
This page has been removed intentionally to protect sensitive

\author{
cultural materials
}

Figure 17 
A total of 12 shovel tests were excavated within the Pond B boundaries, and one newly documented historic archeological site, 41B0282, was recorded. Shovel tests within Pond B encountered a soil profile of brown (7.5YR 4/3) sandy loam to an average depth of $30 \mathrm{cmbs}$ over dark gray (7.5YR 3/1) sandy clay. Some shovel tests encountered dense fill gravel near the surface, probably brought in prior to construction of the mid-century building at 41B0282.

\section{Archeological Sites:}

\section{B0282}

Site $41 \mathrm{BO} 282$ is a 1.9-acre site located in the City of West Columbia, off the western side of SH 36 (South Columbia Drive) and within the south and central portion of the proposed Pond B. The northern part of this area is now a vacant lot that was covered with tall grass and wildflowers at the time of survey (Figure 18.). The southern part of the site is moderately to densely wooded, and a house and backyard are located in the southeast corner of the site. This house is not present in a 1944 aerial image, and a previous historic resources survey found this house to not be a historic resource (Moss 2001).

Twelve shovel tests were excavated in and around the site, five of which contained cultural materials (see Table 3). Shovel tests GW6, GW11, and GW12 all encountered gravel mixed with oyster shells between 10 and $15 \mathrm{cmbs}$. Based on local geology, this gravel is not naturally occurring and was likely once part of a driveway, parking lot, or building foundation. Shovel test AG5 contained one brick fragment at $25 \mathrm{cmbs}$. Shovel test GW7 contained one colorless glass vessel shard at 30-35 cmbs. Additionally, a portion of a sidewalk that once lead to a structure was found based on differential vegetation growth (Figure 19); shallow scraping of the area uncovered concrete just below the surface (Figure 20). The sidewalk extended westward from the edge of present SH 36 for a length of $20 \mathrm{~m}$ (64 feet). Based on a 1944 aerial photograph (see Figure 4), the structure at this site measured approximately 70 feet east to west by 50 feet north to south at its widest point. Ultimately, the site boundaries were determined by the location of positive shovel tests, a feature (a sidewalk), and historic property boundaries. The site likely extends north, where access was not available at the time of survey; however, no features were visible from the surveyed parcel and it is unlikely that significant deposits are present in that location.

Based on historic aerial photos and deed research, this site is the former location of a structure that was used from the 1940s-1960s by various auxiliary groups related to the West Columbia Chamber of Commerce. No part of the structure remains on the surface. Deed research of the property on which site 41B0282 is located shows that the land was surveyed and subdivided into its current lot sizes and configuration in 1933 when it was platted as the Brazoria County State Bank Subdivision (3/115 Brazoria County Plat Records). The Bank had acquired the property that would become the subdivision earlier that year from Robert Galbraith Burkhart when he filed for bankruptcy and the land was sold at public auction (242/554 Brazoria County deed records). In 1941 Brazoria County State Bank sold lots 14-16 of its subdivision to the Ladies Auxiliary of the West Columbia Chamber of Commerce (348/383 Brazoria County deed records). In 1965 the Ladies Auxiliary, by then known as the Civic Club of West 
Columbia, sold the property along with its building and improvements to the West Columbia Junior Chamber of Commerce (926/243 Brazoria County Deed Records).

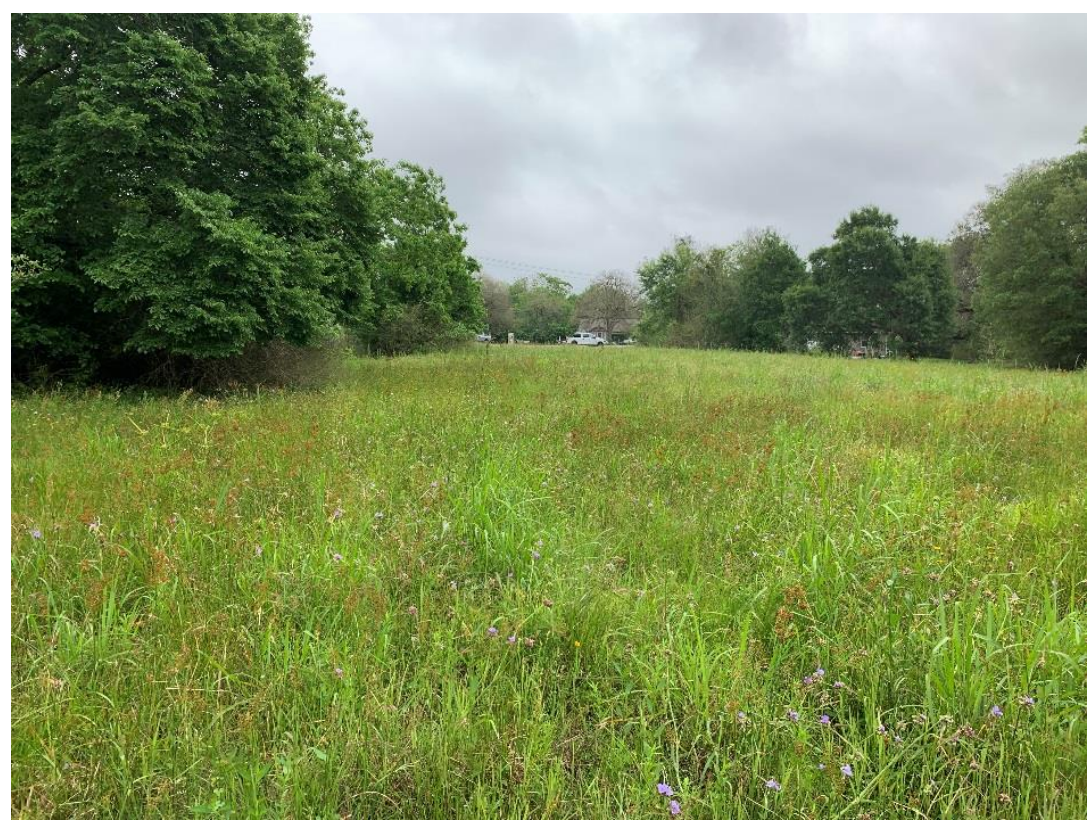

Figure 18. Vacant lot at site 41B0282 from shovel test AG5, facing east.

Figure 19. Differential vegetation growth above former sidewalk, facing west.

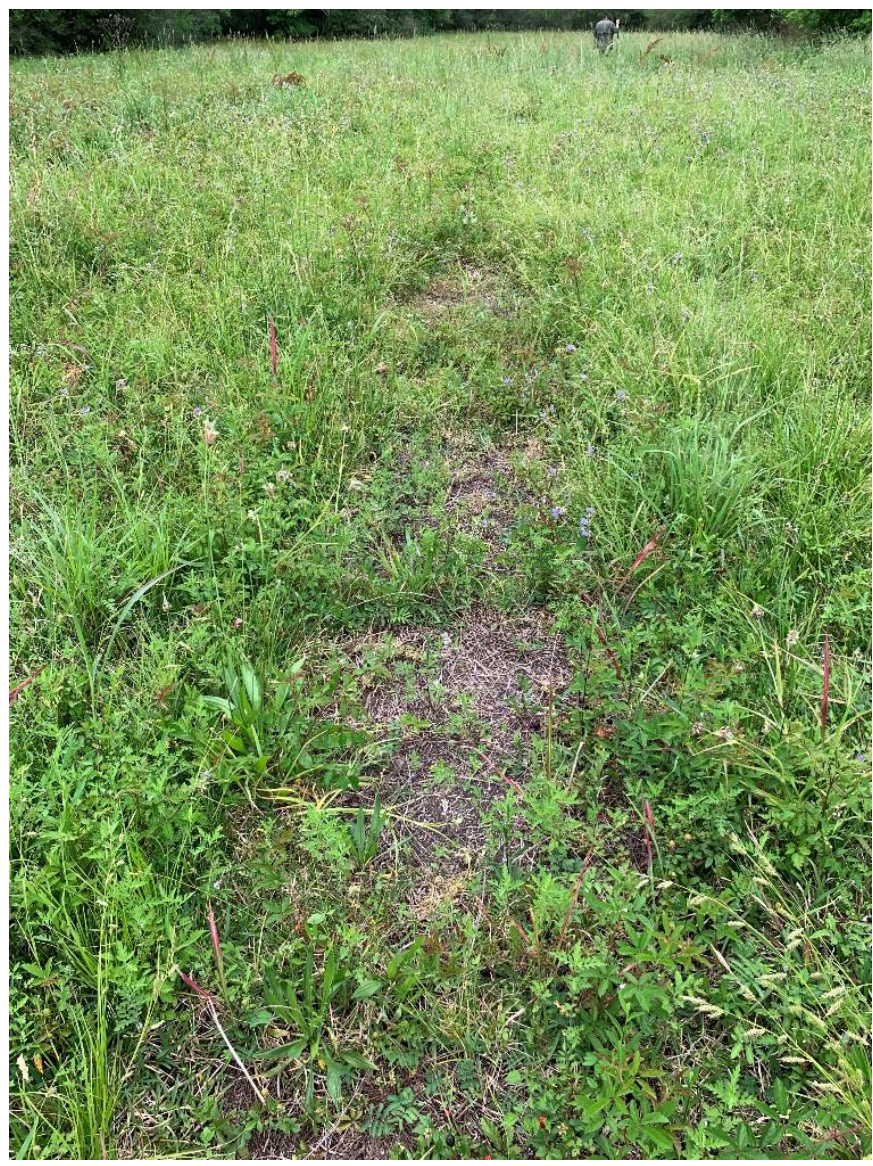




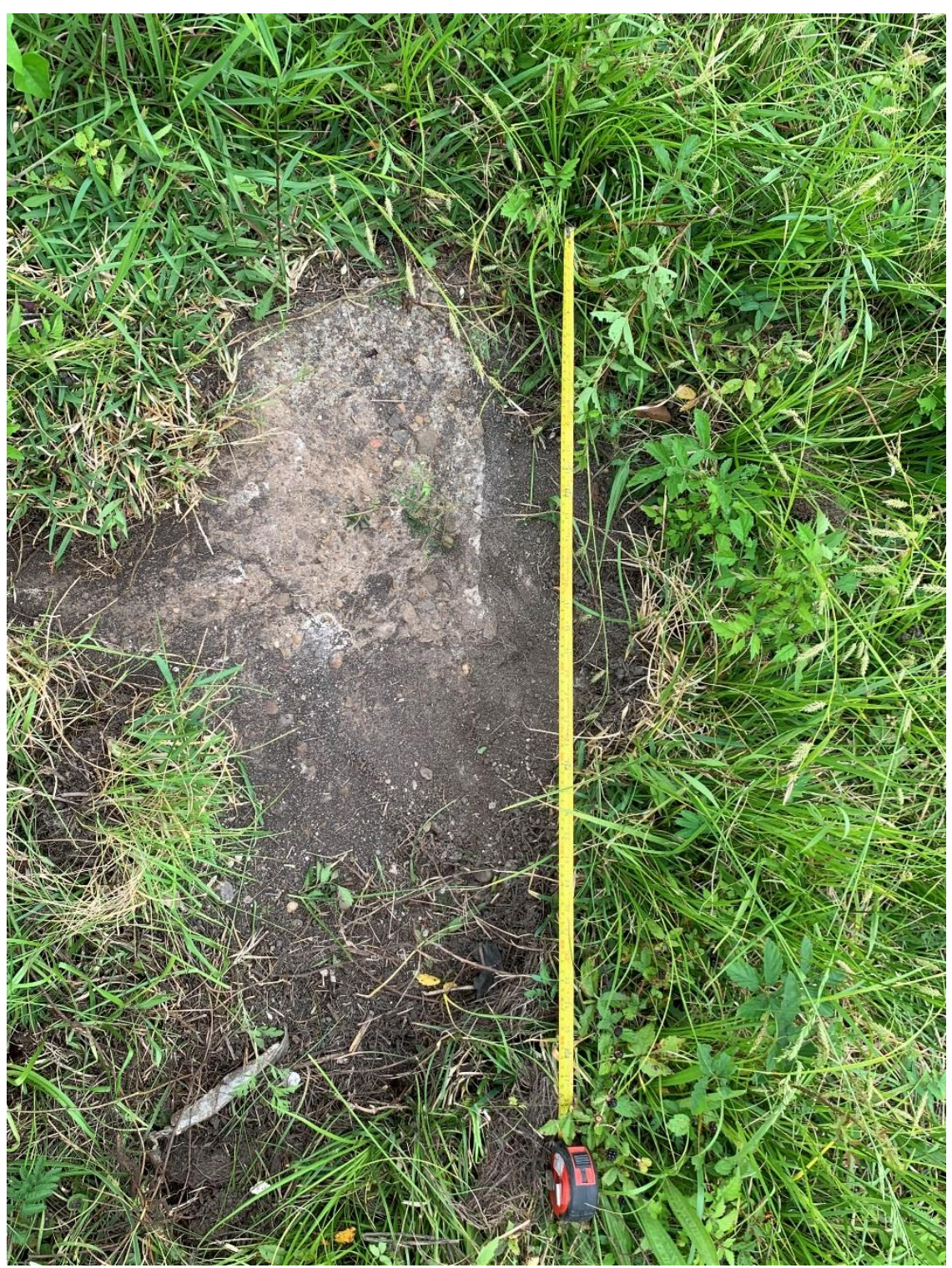

Figure 20. Concrete sidewalk remnants just below the surface. 
Since no structures or other improvements were mentioned in the deed when the property was purchased from the Bank, it is likely that the Ladies Auxiliary of the West Columbia Chamber of Commerce constructed the building shortly after buying the property in 1941. The deed transferring the property from the Civic Club to the Junior Chamber of Commerce states that the building on the property was to be used "primarily for the promotion of educational and recreational programs for the youth and young people of the community..." (926/243 Brazoria County deed records). This deed also specified that should the Junior Chamber of Commerce cease to be an active organization, ownership of the property would transfer to the City of West Columbia. Since the City of West Columbia sold the property to James and Claudine Bohlar in 1980, the Junior Chamber of Commerce must have been defunct by that point.

Overall, very little evidence of the structure that once stood at $41 \mathrm{BO} 282$ remains. The artifacts and features that were found at the site were nondiagnostic; further archeological work would not yield important data. Archival research indicates that the site was not associated with persons or events important to local history. For these reasons, site 41B0282 is recommended not eligible for listing in the NRHP or as a SAL and construction should proceed without further work.

- Buffer Zone Description: No buffer zone recommended for surveyed portions of the APE.

- Archeological Materials Identified: Brick fragment, colorless vessel glass, gravel (not natural, brought in for building pad).

- APE Integrity: The Varner Creek detention pond location showed no signs of disturbance beyond cattle trampling and plowing. The surface of the Pond A portion of the APE has been greatly altered by paving and construction staging; subsurface integrity could not be assessed. The Pond B location has variable integrity: structures within the north and central portion were razed at some point, and some shovel tests found mottling and other signs of disturbance in the upper $40 \mathrm{~cm}$. The southern portion of Pond B showed no evidence of subsurface disturbance. Finally, the proposed Big Creek 1 and Big Creek 2 pond locations could not be assessed for integrity due to lack of access.

\section{Recommendations}

- One new archeological site was recorded during this survey: 41B0282. This is a mid-twentieth century site that was once the location of a building belonging to the Ladies Auxiliary of the West Columbia Chamber of Commerce and the West Columbia Junior Chamber of Commerce. One brick fragment, one glass shard, fill gravel, and part of a concrete sidewalk are the only archeological evidence of the site that remains within the APE. Since the site is unlikely to yield important data, it is recommended as not eligible for listing in the NRHP, and no further work is recommended.

- The proposed Pond A location was found to be entirely developed and altered beyond the possibility to contain archeological deposits and no further work is recommended at this location. 
- The proposed Varner Creek detention pond was intensively surveyed, and no evidence of cultural material was found; no further work is recommended at this location.

- The proposed Big Creek 1 and Big Creek 2 pond locations could not be accessed for survey. AmaTerra recommends that these proposed pond locations be surveyed prior to construction.

Results Valid Within (check all that apply to define the buffer zone):

- No Survey Area (NSA)

- $\square$ _ 50 feet of NSA

- $\square \_$feet of NSA

- Survey Area

- $\square 50$ feet of survey area

- $\bigotimes 25$ feet of survey area

- Either

The Definition and Evaluation of this Horizontal Buffer Zone Is Based on One or More of the Following Considerations (check all that apply):

- $\bigotimes$ The integrity of the areas within and adjacent to the setting is affected by prior clear cutting and ranching activities.

- $\bigotimes$ The survey shows that archeological materials are unlikely to exist in this area.

- $\square$ Other

(specify):

- Archeological Site Evaluations: 4180282

- Comments on Evaluations: Although site 41B0282 may extend slightly further north, historic aerial photos suggest the vast majority of the site is within the surveyed area. The surveyed portion of the site shows no additional data potential for 41B0282; the site is therefore recommended not eligible for the NRHP.

- Further Work: No further work is recommended in the Varner Creek, Pond A or Pond B detention pond locations. Intensive archeological survey is recommended for the Big Creek 1 and Big Creek 2 locations.

- Justification: The Varner Creek and Pond B locations were subject to intensive archeological survey. No cultural material was found within the Varner Creek APE. The archeological site (41B0282) found within the Pond B APE has no further data potential and is recommended not eligible. Pond A was visually inspected from the existing ROW and found to be entirely disturbed by construction activities and paving. The two remaining proposed pond locations, Big Creek 1 and Big Creek 2, could not be surveyed at this time. 


\section{References Cited}

Abbott, James T.

2001 Houston Area Geoarcheology: A Framework for Archeological Investigation, Interpretation, and Cultural Resource Management in the Houston Highway District. Texas Department of Transportation, Environmental Affairs Division, Archeological Studies Program, Report No. 27. Austin, Texas.

Gould, Frank W.

1978 Common Texas Grasses: An Illustrated Guide. Texas A\&M University Press, College Station.

Moss, Sue Winton

2001 Historical Cultural Resources Survey Spur 10 (Hartledge Road) from US 59 to SH 36, SH 36 from FM2218 to FM 1495, Fort Bend and Brazoria Counties, Texas. Technical Report.

Omernik, G.E., and J. M. Griffith

2009 Ecoregions of Texas (EPA) - The Encyclopedia of Earth. Electronic document, http://www.eoearth.org/view/article/152207/, accessed March 2019.

Texas Historical Commission (THC)

2019 Texas Archeological Sites Atlas. Electronic database. Available at: https://atlas.thc.state.tx.us/ , accessed April 2019.

United States Department of Agriculture, Natural Resources Conservation Service (USDA-NRCS)

2019 Fort Bend County, Texas - Web Soil Survey. Electronic document, http://websoilsurvey.nrcs.usda.gov/app/WebSoilSurvey.asp, accessed March 2019. 
THIS PAGE IS INTENTIONALLY BLANK 
Attachment A-Shovel Tests 
THIS PAGE IS INTENTIONALLY BLANK 


\begin{tabular}{|c|c|c|c|c|c|c|c|}
\hline $\begin{array}{l}\text { Assoc. } \\
\text { Site }\end{array}$ & $\begin{array}{l}\text { Shovel } \\
\text { Test }\end{array}$ & Easting & Northing & $\begin{array}{l}\text { Depth } \\
(\mathrm{cm})\end{array}$ & Color & Texture & $\begin{array}{l}\text { Cultural } \\
\text { material }\end{array}$ \\
\hline & \multirow[b]{2}{*}{ AG 1} & \multirow[b]{2}{*}{238492} & \multirow[b]{2}{*}{3234099} & $0-30$ & 10 YR 3/1 & $\begin{array}{l}\text { Loamy } \\
\text { Clay }\end{array}$ & \\
\hline & & & & $30-45$ & 10 YR $2 / 1$ & Clay & \\
\hline & AG 2 & 238486 & 3234072 & $0-35$ & 10 YR 2/1 & Clay & \\
\hline & \multirow[b]{2}{*}{ AG 3} & \multirow[b]{2}{*}{238528} & \multirow[b]{2}{*}{3234038} & $0-25$ & 10 YR 2/1 & Clay & \\
\hline & & & & $25-30$ & $\begin{array}{l}10 \text { YR 2/1 } \\
\text { (Mottled w/ } \\
10 \text { YR 4/3) }\end{array}$ & Clay & \\
\hline & \multirow[b]{2}{*}{ AG 4} & \multirow{4}{*}{238555} & \multirow{4}{*}{3233963} & $0-10$ & 10 YR 3/1 & $\begin{array}{l}\text { Loamy } \\
\text { Clay }\end{array}$ & \\
\hline & & & & $10-30$ & 10 YR 2/1 & Clay & \\
\hline \multirow[b]{2}{*}{ 41B0282 } & \multirow[b]{2}{*}{ AG 5} & & & $0-25$ & 10 YR 4/3 & $\begin{array}{l}\text { Sandy } \\
\text { Loam }\end{array}$ & \multirow{2}{*}{$\begin{array}{l}1 \text { Brick Frag - } \\
25 \mathrm{cmbs}\end{array}$} \\
\hline & & & & $25-45$ & $\begin{array}{l}7.5 \text { YR 3/1 } \\
\text { (Mottled w/ } \\
7.5 \text { YR 5/6) }\end{array}$ & $\begin{array}{l}\text { Sandy } \\
\text { Clay }\end{array}$ & \\
\hline \multirow[b]{2}{*}{ 41B0282 } & \multirow[b]{2}{*}{ AG 6} & \multirow[b]{2}{*}{241544} & \multirow[b]{2}{*}{3226726} & $0-35$ & 10 YR 4/3 & $\begin{array}{l}\text { Sandy } \\
\text { Loam }\end{array}$ & \\
\hline & & & & $35-50$ & $\begin{array}{l}7.5 \text { YR 3/1 } \\
\text { (Mottled w/ } \\
7.5 \text { YR 5/6) }\end{array}$ & $\begin{array}{l}\text { Sandy } \\
\text { Clay }\end{array}$ & \\
\hline \multirow[b]{2}{*}{ 41B0282 } & \multirow[b]{2}{*}{ AG 7} & \multirow[b]{2}{*}{241542} & \multirow[b]{2}{*}{3226705} & $0-35$ & 7.5 YR 4/3 & $\begin{array}{l}\text { Sandy } \\
\text { Loam }\end{array}$ & \\
\hline & & & & $35-50$ & $\begin{array}{l}7.5 \text { YR } 4.1 \\
\text { (Mottled w/ } \\
7.5 \text { YR 4/4 } \\
\& 7 / 1 \text { ) }\end{array}$ & $\begin{array}{l}\text { Sandy } \\
\text { Clay }\end{array}$ & \\
\hline \multirow[b]{3}{*}{ 41B0282 } & \multirow[b]{3}{*}{ AG 8} & \multirow[b]{3}{*}{241564} & \multirow[b]{3}{*}{3226669} & $0-5$ & 7.5 YR 3/2 & $\begin{array}{l}\text { Sandy } \\
\text { Loam }\end{array}$ & \\
\hline & & & & $5-30$ & 7.5 YR 4/3 & $\begin{array}{l}\text { Sandy } \\
\text { Loam }\end{array}$ & \\
\hline & & & & $30-35$ & $\begin{array}{l}7.5 \text { YR 3/1 } \\
\text { (Mottled w/ } \\
5 / 8 \text { ) }\end{array}$ & $\begin{array}{l}\text { Sandy } \\
\text { Clay }\end{array}$ & \\
\hline \multirow{5}{*}{ 41B0282 } & \multirow[b]{2}{*}{ AG 9} & \multirow[b]{2}{*}{241595} & \multirow[b]{2}{*}{3226704} & $0-40$ & 7.5 YR 4/3 & $\begin{array}{l}\text { Sandy } \\
\text { Loam }\end{array}$ & \\
\hline & & & & $40-50$ & $\begin{array}{l}7.5 \text { YR 3/2 } \\
\text { (Mottled) }\end{array}$ & $\begin{array}{l}\text { Sandy } \\
\text { Clay } \\
\text { Loam }\end{array}$ & \\
\hline & GW1 & 0238470 & 3234128 & $0-35$ & 2.5 YR $2.5 / 1$ & Clay & \\
\hline & GW2 & & & $0-30$ & 2.5 YR $2.5 / 1$ & Clay & Modern Glass \\
\hline & GW3 & 0238466 & 3234057 & $0-45$ & 2.5 YR $2.5 / 1$ & Clay & \\
\hline
\end{tabular}




\begin{tabular}{|c|c|c|c|c|c|c|c|}
\hline $\begin{array}{l}\text { Assoc. } \\
\text { Site }\end{array}$ & $\begin{array}{l}\text { Shovel } \\
\text { Test }\end{array}$ & Easting & Northing & $\begin{array}{l}\text { Depth } \\
(\mathrm{cm})\end{array}$ & Color & Texture & $\begin{array}{l}\text { Cultural } \\
\text { material }\end{array}$ \\
\hline & GW4 & 0238494 & 3233990 & $0-30$ & 2.5 YR $2.5 / 1$ & Clay & \\
\hline & GW5 & 0238520 & 3233920 & $0-35$ & 2.5 YR $2.5 / 1$ & Clay & \\
\hline \multirow[b]{2}{*}{ 41B0282 } & \multirow[b]{2}{*}{ GW6 } & & & $0-15$ & 10 YR 4/2 & $\begin{array}{l}\text { Sandy } \\
\text { Loam }\end{array}$ & \multirow{2}{*}{$\begin{array}{l}\text { Oysters Mixed } \\
\text { in w/ Gravel }\end{array}$} \\
\hline & & & & $15-$ & & Gravel & \\
\hline \multirow[b]{2}{*}{ 41B0282 } & \multirow[b]{2}{*}{ GW7 } & & & $0-35$ & 10 YR 4/2 & $\begin{array}{l}\text { Sandy } \\
\text { Loam }\end{array}$ & \multirow{2}{*}{$\begin{array}{l}\text { Glass Frag - } \\
\text { Clear @ } 30 \text { - } \\
35 \text { cmbs }\end{array}$} \\
\hline & & & & $35-50$ & 10 YR 5/2 & Clay & \\
\hline \multirow[b]{2}{*}{ 41B0282 } & \multirow[b]{2}{*}{ GW8 } & \multirow[b]{2}{*}{0241523} & \multirow[b]{2}{*}{3226697} & $0-15$ & 10 YR 5/2 & $\begin{array}{l}\text { Clay } \\
\text { Loam }\end{array}$ & \\
\hline & & & & $15-30$ & 10 YR 5/2 & Clay & \\
\hline \multirow[b]{2}{*}{ 41B0282 } & \multirow[b]{2}{*}{ GW9 } & \multirow[b]{2}{*}{0241526} & \multirow[b]{2}{*}{3226668} & $0-10$ & 10 YR 5/2 & $\begin{array}{l}\text { Clay } \\
\text { Loam }\end{array}$ & \\
\hline & & & & $10-25$ & 10 YR 5/2 & Clay & \\
\hline \multirow[b]{2}{*}{ 41B0282 } & \multirow[b]{2}{*}{ GW10 } & & & $0-40$ & 10 YR 4/2 & $\begin{array}{l}\text { Sandy } \\
\text { Loam }\end{array}$ & \\
\hline & & & & $40-60$ & 10 YR 5/2 & Clay & \\
\hline \multirow[b]{4}{*}{ 41B0282 } & \multirow[b]{4}{*}{ GW11 } & & & $0-10$ & 10 YR 4/2 & $\begin{array}{l}\text { Sandy } \\
\text { Loam }\end{array}$ & \multirow{4}{*}{$\begin{array}{l}\text { Oyster Shell in } \\
\text { Gravel }\end{array}$} \\
\hline & & & & $10-15$ & & Gravel & \\
\hline & & & & $15-40$ & 10 YR 4/2 & $\begin{array}{l}\text { Sandy } \\
\text { Loam }\end{array}$ & \\
\hline & & & & $40-55$ & 10 YR 5/2 & Clay & \\
\hline \multirow[b]{2}{*}{ 41B0282 } & \multirow[b]{2}{*}{ GW12 } & & & $0-4$ & 10 YR 4/2 & $\begin{array}{l}\text { Sandy } \\
\text { Loam }\end{array}$ & \multirow[t]{2}{*}{$\begin{array}{l}\text { Oyster Shell in } \\
\text { Gravel }\end{array}$} \\
\hline & & & & $4-12$ & & Gravel & \\
\hline
\end{tabular}


This report was written on behalf of the Texas Department of Transportation by:

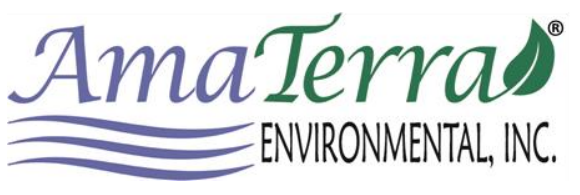

11842 Rim Rock Trail

Austin, Texas 78737 